\title{
ZUSGS
}

science for a changing world

Prepared in cooperation with the U.S. Department of the Army

\section{Summary of Hydrologic Testing of the Floridan Aquifer System at Fort Stewart, Georgia}


Cover. Well drillers observing hydrologic monitoring equipment during the 72-hour aquifer test at Lower Floridan aquifer well 33P028, Fort Stewart, Liberty County, Georgia. Discharge from the aquifer test is being transported away from the well site. Fires in the background are control burning for brush control. Photo by Michael D. Hamrick, U.S. Geological Survey, 2010. 


\section{Summary of Hydrologic Testing of the Floridan Aquifer System at Fort Stewart, Georgia}

By Gerard J. Gonthier

Prepared in cooperation with the U.S. Department of the Army

Open-File Report 2011-1020 


\title{
U.S. Department of the Interior \\ KEN SALAZAR, Secretary \\ U.S. Geological Survey \\ Marcia K. McNutt, Director
}

\section{U.S. Geological Survey, Reston, Virginia: 2011}

\author{
For more information on the USGS — the Federal source for science about the Earth, its natural and living resources, \\ natural hazards, and the environment, visit http://Www.usgs.gov or call 1-888-ASK-USGS \\ For an overview of USGS information products, including maps, imagery, and publications, \\ visit http://www.usgs.gov/pubprod \\ To order this and other USGS information products, visit http://store.usgs.gov
}

Any use of trade, product, or firm names is for descriptive purposes only and does not imply endorsement by the U.S. Government.

Although this report is in the public domain, permission must be secured from the individual copyright owners to reproduce any copyrighted materials contained within this report.

Suggested citation:

Gonthier, G.J., 2011, Summary of hydrologic testing of the Floridan aquifer system at Fort Stewart, Georgia: U.S. Geological Survey Open-File Report 2011-1020, 28 p. 


\section{Contents}

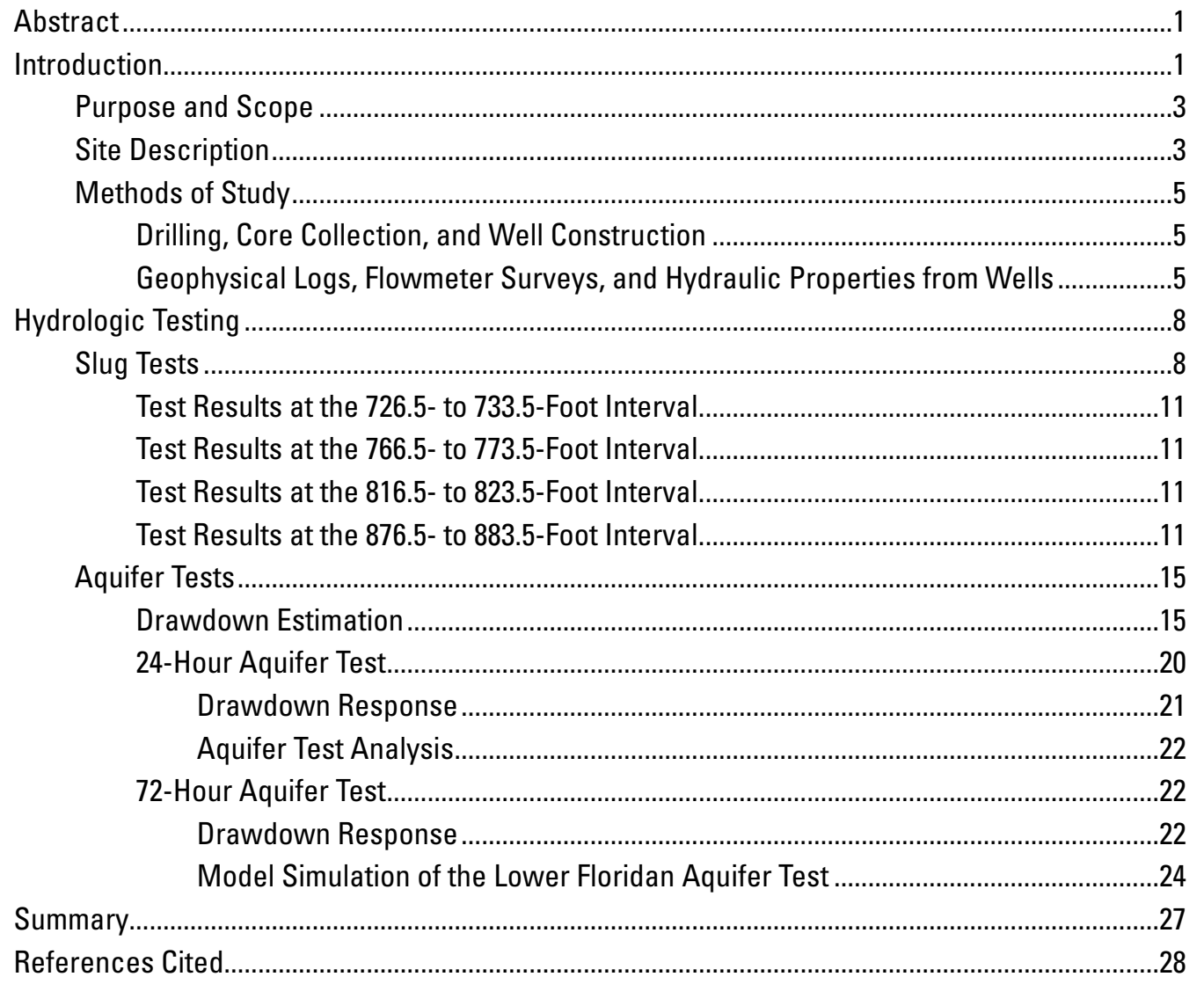




\section{Figures}

1. Map showing location of study, selected wells, and weather station at Fort Stewart and vicinity, GA.

2. Generalized correlation of geologic and hydrogeologic units in the Coastal Plain of Georgia....

3. Well-construction diagrams for well 33P028 and well 33P029 at

Fort Stewart, GA, 2010

4-11. Graphs showing-

4. Selected borehole geophysical data and percent flow contribution from permeable zones in borehole 33P028, 460-1,300 feet at Fort Stewart, GA, 2010 ......6

5. Flowmeter survey data from pumping the Upper and Lower Floridan aquifers prior to installing a 14-inch casing in borehole 33P028, and pumping the Lower Floridan aquifer after installing a 14-inch casing in borehole 33P028 and completing it as well $33 \mathrm{P} 028$ at Fort Stewart, GA.

6. Measured and simulated water levels and simulated water-injection volumes for packer-isolated interval 726.5- to 733.5-feet in borehole 33P028 at Fort Stewart, GA, December 5, 2009, for Test 1, 5-gallon slug test, and Test 2, 10-gallon slug test.

7. Slightly underdamped water-level responses to a 10-gallon slug of water injected into packer-isolated interval 766.5- to 773.5-feet in borehole 33P028 at Fort Stewart, GA, December 6, 2009.

8. Measured and simulated water levels for test 1 in the packer-isolated interval 766.5- to 773.5-feet in borehole 33P028 at Fort Stewart, GA, December 6, 2009. Log of absolute value of displacement as a function of time, used to determine damping coefficient $\gamma$, and water displacement as a function of time, used to determine oscillation frequency $\omega$.

9. Measured and simulated water levels for test 2 in the packer-isolated interval 766.5- to 773.5-feet in borehole 33P028 at Fort Stewart, GA, December 6, 2009. Log of absolute value of displacement as a function of time, used to determine damping coefficient $\gamma$, and water displacement as a function of time, used to determine oscillation frequency $\omega$.

10. Measured and simulated water levels and simulated injection of water for packer-isolated interval 816.5- to 823.5-feet in borehole 33P028 at Fort Stewart, GA, December 6, 2009, Test 1 and Test 2

11. Measured and simulated water levels and simulated injection of water for packer-isolated interval 876.5- to 883.5-feet in borehole 33P028 at Fort Stewart, GA, December 6, 2009, for Test 1 and Test 2 
12. Diagrams showing location and open interval of wells used for the 72-hour aquifer test at Fort Stewart, GA. Diagram showing aquifer-test layout, and schematic cross section showing the open intervals of the wells in relation to major hydrogeologic units

13-22. Graphs showing-

13. Raw, unfiltered water levels in wells 33P023, 33P029, and $33 \mathrm{P} 025$ before, during, and after the 24-hour Upper Floridan and 72-hour Lower Floridan aquifer tests at Fort Stewart, GA, March 1-15, 2010

14. Water-level fluctuations in monitored wells and background wells and fluctuations in barometric pressure and gravity, used in the aquifer tests at Fort Stewart, GA, January 27-March 16, 2010, for fitting period for well 33P028, Upper Floridan 24-hour aquifer test, and Lower Floridan 72-hour aquifer test.

15. Measured and synthetic water levels for well 33P028 during fitting period, January 31-March 1, 2010, at Fort Stewart, GA

16. Fit of synthetic water levels to measured water levels for wells 33P028, 33P029, and 33P025, Fort Stewart, GA, February 25-March 2, 2010.

17. Water levels at the start and end of the 24-hour aquifer test in well 33P029 at Fort Stewart, GA, March 3-4, 2010.

18. Semi-log graph of drawdown during the 24-hour aquifer test in well $33 \mathrm{P} 029$ at a pumping rate of 387 gallons per minute at Fort Stewart, GA, March 3-4, 2010

19. Measured and synthetic water levels and estimated drawdown in wells 33P025 and 33P028 during the 24-hour aquifer test conducted in the Upper Floridan aquifer well 33P029 at Fort Stewart, GA, February 25-March 7, 2010

20. Effects on water level in well $33 \mathrm{P} 028$ at the end of the 72-hour aquifer test when a slug of water siphoned back into the well immediately after pumping stopped at Fort Stewart, GA, March 11, 2010

21. Measured and synthetic water levels and estimated drawdown in wells 33P025 and 33P029 during the 72-hour aquifer test conducted in Lower Floridan aquifer well 33P028 at Fort Stewart, GA, March 5-15, 2010

22. Semi-log plot of drawdown in pumped well 33P028 during the 72-hour aquifer test at Fort Stewart, GA, March 8-11, 2010

23. Diagram showing axisymmetric radial model for 72-hour aquifer test at pumped well 33P028 at Fort Stewart, GA, March 8-11, 2010.

24. Graph showing simulated and measured water-level drawdown and recovery at pumped well 33P028 and observation wells 33P029 and 33P025 for the 72-hour aquifer test at Fort Stewart, GA, March 8-11, 2010. 


\section{Tables}

1. Location and open intervals of wells used in the slug-test and aquifer-test analyses at Fort Stewart, GA, 2009-2010.

2. Estimated vertical hydraulic conductivity and porosity of core samples collected from the Lower Floridan confining unit in borehole 33P028 at Fort Stewart, GA ..............8

3. Slug times for packer-isolated intervals in borehole 33P028 at Fort Stewart, GA, December 5-6, 2009

4. Total injection volume and test-specific values for parameters used with the Bouwer and Rice (1976) method to estimate hydraulic conductivity 10

5. Hydraulic conductivity values for packer-isolated intervals in borehole 33P028 in the Lower Floridan confining unit at Fort Stewart, GA, December 5-6, 2009.

6. Summary of aquifer test results, Fort Stewart, GA, March 2010

7. Hydraulic parameters that were used or estimated to fit simulated water levels to measured drawdown and recovery and estimated values of transmissivity and storativity for the 72-hour aquifer test at pumped well 33P028 and observation wells 33P029 and 33P025, Fort Stewart, GA, March 8-11, 2010

\section{Acknowledgments}

Many people participated in the successful completion of this study. Special thanks go to Troy Funk and David Deloach of the U.S. Army Corps of Engineers, and Stanley Thomas, Eric Stulpin, Brent Rabon, and Tressa Rutland of the U.S. Army Environmental Protection and Compliance Branch. Troy Leeson of Layne-Atlantic Drilling provided valuable assistance for onsite data collection.

O. Gary Holloway, U.S. Geological Survey (USGS), designed and constructed the aquifer-test plumbing to remove discharge water from the site and determine discharge rate. Gary Holloway and Michael D. Hamrick, USGS, monitored drill-site activities and collected hydrogeologic and water-quality data. John S. Clarke, USGS, helped perform the slug tests and provided figures for this report. Keith J. Halford, USGS, completed the model simulation of the Lower Floridan aquifer test, and Lester J. Williams, USGS, analyzed flowmeter survey data. 


\section{Conversion Factors}

\begin{tabular}{lcl}
\hline & Multiply & \multicolumn{1}{c}{ To obtain } \\
\hline inch & Length & \\
inch & 2.54 & centimeter $(\mathrm{cm})$ \\
foot (ft) & 25.4 & millimeter $(\mathrm{mm})$ \\
mile (mi) & 0.3048 & meter (m) \\
yard (yd) & 1.609 & kilometer $(\mathrm{km})$ \\
\hline & 0.9144 & meter $(\mathrm{m})$ \\
\hline gallon (gal) & Volume & \\
gallon (gal) & 3.785 & liter $(\mathrm{L})$ \\
gallon (gal) & 0.003785 & cubic meter $\left(\mathrm{m}^{3}\right)$ \\
& 3.785 & cubic decimeter $\left(\mathrm{dm}{ }^{3}\right)$ \\
\hline gallon per minute $(\mathrm{gal} / \mathrm{min})$ & Flow rate & liter per second $(\mathrm{L} / \mathrm{s})$ \\
gallon per day (gal/d) & 0.06309 & cubic meter per day $\left(\mathrm{m}^{3} / \mathrm{d}\right)$ \\
\hline & 0.003785 & \\
\hline foot per day (ft/d) & Hydraulic conductivity & meter per day $(\mathrm{m} / \mathrm{d})$ \\
\hline & 0.3048 & meter squared $\mathrm{per} \mathrm{day}\left(\mathrm{m}^{2} / \mathrm{d}\right)$ \\
\hline foot squared per day (ft $\left.{ }^{2} / \mathrm{d}\right)$ & Transmissivity & \\
\hline
\end{tabular}

Temperature in degrees Celsius $\left({ }^{\circ} \mathrm{C}\right)$ may be converted to degrees Fahrenheit $\left({ }^{\circ} \mathrm{F}\right)$ as follows:

$$
{ }^{\circ} \mathrm{F}=\left(1.8 \times{ }^{\circ} \mathrm{C}\right)+32
$$

Temperature in degrees Fahrenheit $\left({ }^{\circ} \mathrm{F}\right)$ may be converted to degrees Celsius $\left({ }^{\circ} \mathrm{C}\right)$ as follows:

$$
{ }^{\circ} \mathrm{C}=\left({ }^{\circ} \mathrm{F}-32\right) / 1.8
$$

Vertical coordinate information is referenced to the North American Vertical Datum of 1988 (NAVD 88).

Horizontal coordinate information is referenced to the North American Datum of 1983 (NAD 83).

Altitude, as used in this report, refers to distance above the vertical datum.

*Transmissivity: The standard unit for transmissivity is cubic foot per day per square foot times foot of aquifer thickness $\left[\left(\mathrm{ft}^{3} / \mathrm{d}\right) / \mathrm{ft}^{2}\right] \mathrm{ft}$. In this report, the mathematically reduced form, foot squared per day $\left(\mathrm{ft}^{2} / \mathrm{d}\right)$, is used for convenience.

Specific conductance is given in microsiemens per centimeter at 25 degrees Celsius $(\mu \mathrm{S} / \mathrm{cm}$ at $\left.25^{\circ} \mathrm{C}\right)$. 



\title{
Summary of Hydrologic Testing of the Floridan Aquifer System at Fort Stewart, Georgia
}

\author{
By Gerard J. Gonthier
}

\section{Abstract}

Two test wells were completed at Fort Stewart, GA, in January and February 2010 to investigate the potential of using the Lower Floridan aquifer as a source of water to satisfy anticipated increases in water use. One well was completed in the Lower Floridan aquifer at a depth of 1,255 feet below land surface; the other well was completed in the Upper Floridan aquifer at a depth of 560 feet below land surface. The U.S. Geological Survey conducted hydrologic testing at the well site including flowmeter surveys, slug tests within packerisolated intervals of the Lower Floridan confining unit, and aquifer tests of the Upper and Lower Floridan aquifers.

Flowmeter surveys at the study site indicate several permeable zones within the Floridan aquifer system. The Upper Floridan aquifer is composed of two water-bearing zones - the upper zone and the lower zone. The upper zone extends from 520 to 650 feet below land surface, contributes 96 percent of the total flow, and is more permeable than the lower zone, which extends from 650 to 705 feet below land surface and contributes the remaining 4 percent of the flow. The Lower Floridan aquifer consists of three zones at depths of 912-947, 1,090-1,139, and 1,211-1,250 feet below land surface that are inter-layered with three less-permeable zones. The Lower Floridan confining unit includes a permeable zone that extends from 793 to 822 feet below land surface. Horizontal hydraulic conductivity values of the Lower Floridan confining unit derived from slug tests within four packer-isolated intervals were from 2 to 20 feet per day, with a high value of 70 feet per day obtained for one of the intervals. Aquifer testing, using analytical techniques and model simulation, indicated the Upper Floridan aquifer had a transmissivity of about 100,000 feet squared per day, and the Lower Floridan aquifer had a transmissivity of 7,000 feet squared per day. Flowmeter surveys, slug tests within packer-isolated intervals, and parameter-estimation results indicate that the hydraulic properties of the Lower Floridan confining unit are similar to those of the Lower Floridan aquifer. Water-level data, for each aquifer test, were filtered for external influences such as barometric pressure, earth-tide effects, and long-term trends to enable detection of small water-level responses to aquifer-test pumping of less than 1 foot. During a 72-hour aquifer test of the Lower Floridan aquifer, a drawdown response of 0.3 to 0.4 foot was observed in two Upper Floridan aquifer wells, one of which was more than 1 mile away from the pumped well.

\section{Introduction}

The U.S. Geological Survey (USGS) is assessing the potable water-supply potential of the Floridan aquifer system at Fort Stewart, GA (fig. 1), in cooperation with the U.S. Department of the Army. As development at Fort Stewart increases, water use is anticipated to increase. To meet growing demand, the U.S. Army is installing additional wells at Fort Stewart, including one production well completed in the Lower Floridan aquifer (well 33P028).

Regional drawdown of the Upper Floridan aquifer has caused water-supply concerns in coastal Georgia. As a result of these concerns, the Georgia Environmental Protection Division has instituted pumping restrictions in order to prevent further drawdown in the Upper Floridan aquifer that might accelerate saltwater intrusion in the area of Hilton Head Island, SC (Georgia Environmental Protection Division, 2006). These restrictions include limiting pumping from the Lower Floridan aquifer that may cause drawdown in the Upper Floridan aquifer. Hydrogeologic units in the study area (Payne and others, 2005) are shown in figure 2. 


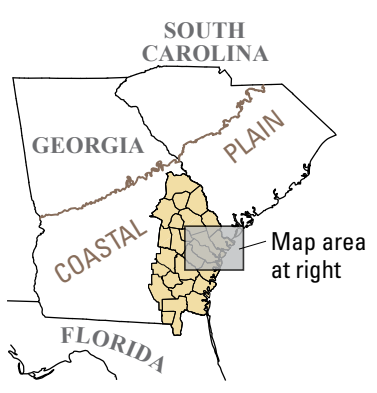

\section{EXPLANATION}

24-county coastal Georgia area as identified by the Georgia Environmental Protection Division

\section{Fort Stewart}

Hunter Army Airfield

- 0 - Potentiometric contour May 1998Hachures indicate depression. Contour interval, 10 feet. Datum is NAVD 88

\section{KLHW National Weather Service precipitation station and identifier \\ 33M004 ${ }^{\circ}$ Well and identifier}
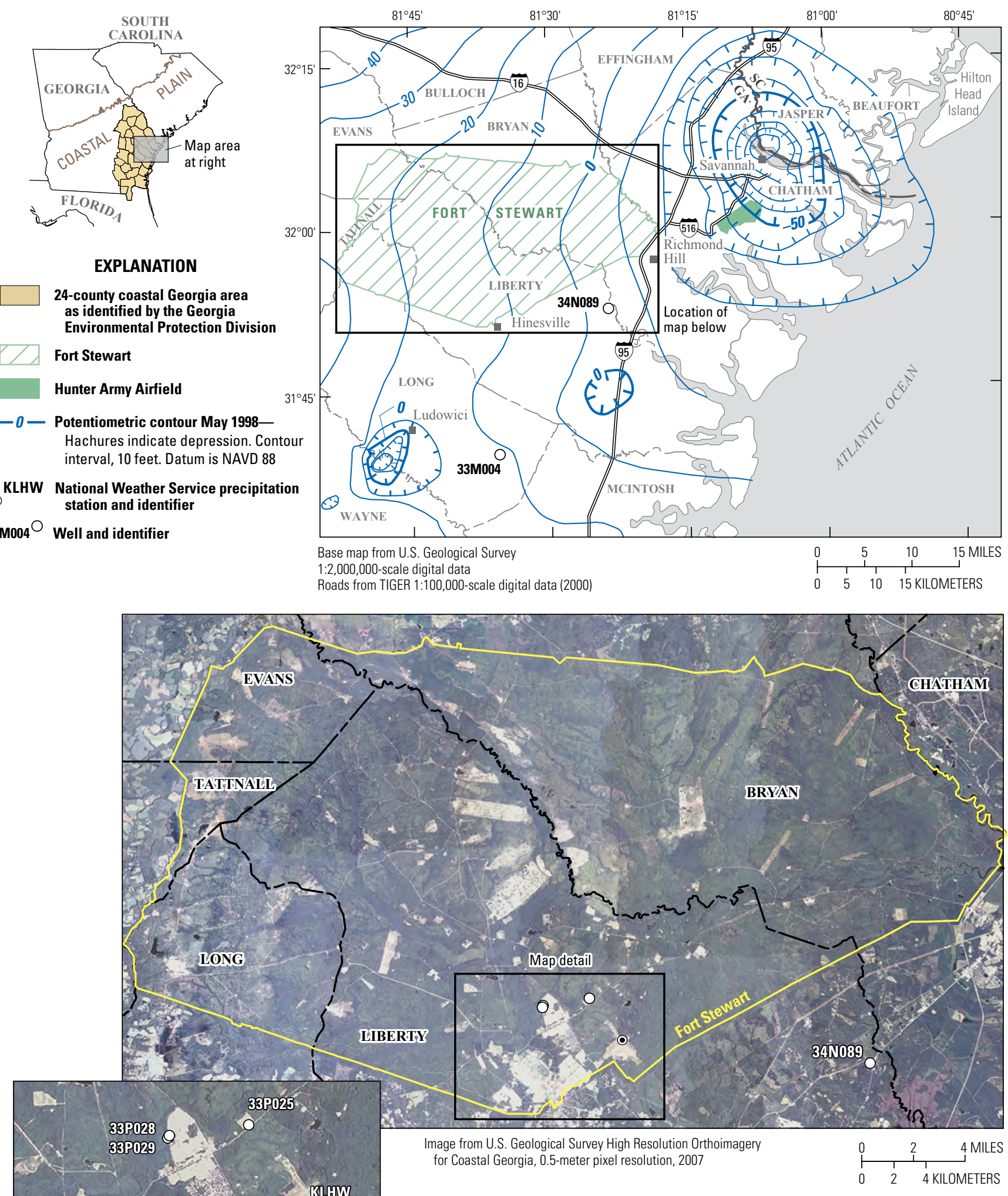

Figure 1. Location of study area, selected wells, and weather station at Fort Stewart and vicinity, GA (potentiometric contours modified from Peck and others, 1999). 


\begin{tabular}{|c|c|c|c|c|c|}
\hline \multirow{3}{*}{\multicolumn{2}{|c|}{ Series }} & \multicolumn{4}{|c|}{ Lower Coastal Plain } \\
\hline & & \multirow{2}{*}{ Geologic unit ${ }^{1}$} & \multicolumn{2}{|c|}{ Hydrogeologic unit ${ }^{2}$} & \\
\hline & & & Savannah & Brunswick & \\
\hline \multicolumn{2}{|c|}{ Post-Miocene } & Undifferentiated & \multicolumn{2}{|c|}{ Water-table zone } & 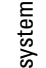 \\
\hline \multirow{4}{*}{ Miocene } & 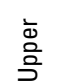 & Ebenezer Formation & $\underset{\text { unit }}{\text { Confining }}<$ & $\begin{array}{l}\text { Upper water- } \\
\text { bearing zone }\end{array}$ & $\frac{\bar{\pi}}{\frac{\pi}{\sigma o \pi}}$ \\
\hline & & & & & \\
\hline & $\frac{\overline{\bar{z}}}{\overline{\frac{0}{2}}}$ & Coosawhatchie Formation & \multirow{4}{*}{$\begin{array}{c}\text { Confining } \\
\text { unit }\end{array}$} & & $\begin{array}{c}E \\
\text { 总 } \\
\text { के } \\
\text { के }\end{array}$ \\
\hline & & Marks Head Formation & & $\sum \begin{array}{c}\text { Brunswick } \\
\text { aquifer }\end{array}$ & 言 \\
\hline & $\sum_{0}^{\infty}$ & Parachucla Formation & & & $\frac{0}{3}$ \\
\hline \multirow{3}{*}{\multicolumn{2}{|c|}{ Oligocene }} & Tiger Leap Formation & & $\sum \begin{array}{c}\text { Brunswick } \\
\text { aquifer }\end{array}$ & 离 \\
\hline & & Lazaretto Creek Formation & \multicolumn{3}{|c|}{ Upper Floridan confining unit } \\
\hline & & Suwannee Limestone & \multirow{3}{*}{$\begin{array}{l}\text { Upper } \\
\text { Floridan } \\
\text { aquifer }\end{array}$} & Upper water- & \\
\hline \multirow{4}{*}{ Eocene } & $\begin{array}{l}\frac{\bar{\alpha}}{2} \\
\frac{0}{2}\end{array}$ & \multirow[t]{2}{*}{ Ocala Limestone } & & \begin{tabular}{|c|} 
Upper \\
$\begin{array}{l}\text { Floridan semi- } \\
\text { confining unit }\end{array}$ \\
\end{tabular} & \\
\hline & & & & $\begin{array}{l}\text { Lower water- } \\
\text { bearing zone }\end{array}$ & \\
\hline & $\frac{0}{\frac{0}{\overline{0}}}$ & Avon Park Formation & \multicolumn{2}{|c|}{$\begin{array}{c}\text { Lower Floridan } \\
\text { confining unit }\end{array}$} & 焉 \\
\hline & 离 & Oldsmar Formation & 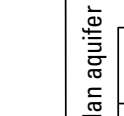 & $\begin{array}{c}\text { Confining } \\
\text { unit }\end{array}$ & $\begin{array}{l}\text { 0 } \\
\text { ㅈ } \\
\frac{\pi}{0} \\
\text { 흔 }\end{array}$ \\
\hline \multicolumn{2}{|c|}{ Paleocene } & Cedar Keys Formation & 峁 & $\begin{array}{l}\text { Fernandina } \\
\text { permeable } \\
\text { zone }\end{array}$ & \\
\hline \multicolumn{2}{|c|}{$\begin{array}{c}\text { Upper } \\
\text { Cretaceous }\end{array}$} & Undifferentiated & \multicolumn{2}{|c|}{ Confining unit } & \\
\hline
\end{tabular}

${ }^{1}$ Modified from Randolph and others, 1991; Weems and Edwards, 2001

2Modified from Randolph and others, 1991; Clarke and Krause, 2000

Figure 2. Generalized correlation of geologic and hydrogeologic units in the Coastal Plain of Georgia.

\section{Purpose and Scope}

Site-specific hydrologic testing was conducted in late 2009 and early 2010 to determine the hydraulic characteristics of the Upper Floridan aquifer, Lower Floridan confining unit, and Lower Floridan aquifer in the vicinity of the production well proposed at Fort Stewart, GA. This report provides a brief description of geophysical logging and flowmeter surveys and summarizes:

- Slug tests conducted within packer-isolated intervals of the Lower Floridan confining unit between the Upper and Lower Floridan aquifers before the Lower Floridan well was completed,

- A 24-hour aquifer test of the Upper Floridan aquifer, and

- A 72-hour aquifer test of the Lower Floridan aquifer.
Also summarized within this report are test analyses and results. Location and construction details for the wells used in the slug tests and aquifer tests at Fort Stewart are included in table 1 .

Two new wells were drilled as part of this study at Fort Stewart, Georgia — one in the Lower Floridan aquifer and one in the Upper Floridan aquifer (fig. 3). Data collection included geophysical logging, flowmeter surveys, slug tests within packer-isolated intervals of the Lower Floridan confining unit, a 24-hour aquifer test in the Upper Floridan aquifer, and a 72-hour aquifer test in the Lower Floridan aquifer. Water levels in both newly drilled wells and an existing third well in the Upper Floridan were monitored during both aquifer tests. In addition to the three wells used to directly monitor the aquifer tests, background water levels from two distant wells in the Upper Floridan were used to filter non-pump water-level influences from drawdown, discussed later. The two distant wells (33M004 and 34N089) are part of the Georgia statewide continuous monitoring network and are distant enough to not be affected by aquifer-test pumping but still within the vicinity of the study site, with water-level fluctuations that are similar to those at the study site.

\section{Site Description}

The aquifer-test site is located in the south-central part of Fort Stewart about 3.5 miles (mi) north of Hinesville in Liberty County, GA (fig. 1). Wells 33P028 and 33P029 are 40 feet apart, with a land-surface altitude of approximately 80 feet (ft) above sea level (NAVD88). Observation well 33P025 is located about 9,600 ft to the east of the study site. Background well 33M004 is located 18 mi due south of pumped well 33P028; background well 34N089 is located about 13 mi east of pumped well 33P028.

The study site is underlain by sedimentary rocks and unconsolidated sediments as old as the Cretaceous age (Miller, 1986; fig. 2). Clarke and others (1990) describe geologic units in the area of the study site from Paleocene to Holocene.

The region around the study site is underlain by shallow aquifers and the Floridan aquifer system (Miller, 1986). Clarke and others (1990) describe the groundwater resources in the area of the study site. The shallowest aquifers include the surficial aquifer, upper Brunswick aquifer, and lower Brunswick aquifer, which consist of Miocene and younger sand, clay and carbonate deposits. The base of the lower Brunswick aquifer is composed of a relatively tight, impermeable carbonate layer. The Floridan aquifer system is divided into the Upper and Lower Floridan aquifers in the study area. Miller (1986) noted that components of the Floridan aquifer system are not restricted to stratigraphic boundaries but are almost completely composed of carbonate deposits. Most flow in the Floridan aquifer system occurs in discrete permeable zones that are separated by layers of denser carbonate deposits.

The Upper Floridan aquifer consists of Oligocene limestone and late Eocene limestone and dolostone, and the uppermost part of the aquifer generally is the most permeable. 
However, the Upper Floridan aquifer as a whole consists of several permeable water-bearing zones separated by layers of dense limestone or dolostone. The Upper Floridan aquifer thickness ranges from 200 to $700 \mathrm{ft}$ in the study area (Miller, 1986).

The Upper and Lower Floridan aquifers generally are separated by a confining unit that consists of middle Eocene dense, dolomitic limestone. Thickness of the confining unit that separates the Upper and Lower Floridan aquifers is mapped to be about $200 \mathrm{ft}$ in the study area (Miller, 1986).

The Lower Floridan aquifer consists of middle and early Eocene dolomitic limestone but can include Paleocene and Upper Cretaceous carbonate units. As with the Upper Floridan aquifer, the Lower Floridan aquifer consists of several permeable water-bearing zones that are separated by layers of dense carbonate deposits.

Table 1. Location and open intervals of wells used in the slug-test and aquifer-test analyses at Fort Stewart, GA, $2009-2010$.

[See fig. 1 for site locations; USGS, U.S. Geological Survey; latitude and longitude are in degrees north and east, respectively; UFA, Upper Floridan aquifer; FAS, Floridan aquifer system; LFA, Lower Floridan aquifer; well 33P028 was a bore hole for testing prior to being completed in the LFA; NA, not applicable]

\begin{tabular}{|c|c|c|c|c|c|c|c|c|}
\hline \multirow[b]{2}{*}{$\begin{array}{c}\text { USGS } \\
\text { identifier }\end{array}$} & \multirow[b]{2}{*}{$\begin{array}{l}\text { USGS } \\
\text { site } \\
\text { number }\end{array}$} & \multirow{2}{*}{$\begin{array}{c}\text { Land } \\
\text { elevation } \\
\text { above } \\
\text { NAVD } 1988\end{array}$} & \multicolumn{2}{|r|}{ Longitude } & \multicolumn{3}{|c|}{ Depth, in feet below land surface } & \multirow[b]{2}{*}{ Aquifer } \\
\hline & & & \multicolumn{2}{|c|}{ (Decimal degrees) } & $\begin{array}{c}\text { Static } \\
\text { water level } \\
\text { March 2, } 2010\end{array}$ & $\begin{array}{l}\text { Top of } \\
\text { open } \\
\text { interval }\end{array}$ & $\begin{array}{l}\text { Bottom } \\
\text { of open } \\
\text { interval }\end{array}$ & \\
\hline 33M004 & 313845081361701 & 60.3 & 31.64833 & -81.60111 & 54.34 & 538 & 870 & UFA \\
\hline 33P025 & 315447081345601 & 89 & 31.91315 & -81.58227 & 86.52 & 420 & 520 & UFA \\
\hline 33Р029 & 315434081364702 & 81.36 & 31.90946 & -81.61293 & 77.49 & 460 & 560 & UFA \\
\hline 34N089 & 315214081235301 & 16.01 & 31.87056 & -81.39806 & 23.85 & 410 & 789 & UFA \\
\hline
\end{tabular}

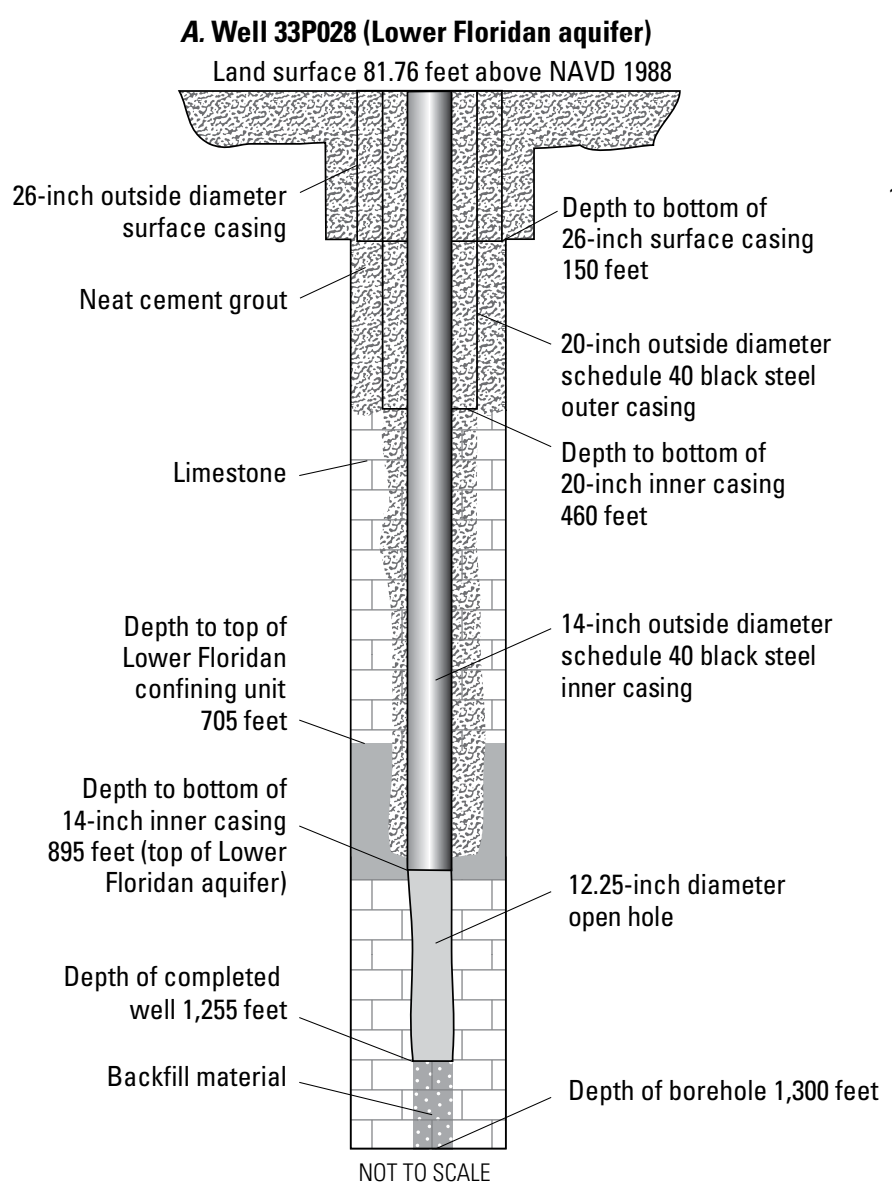

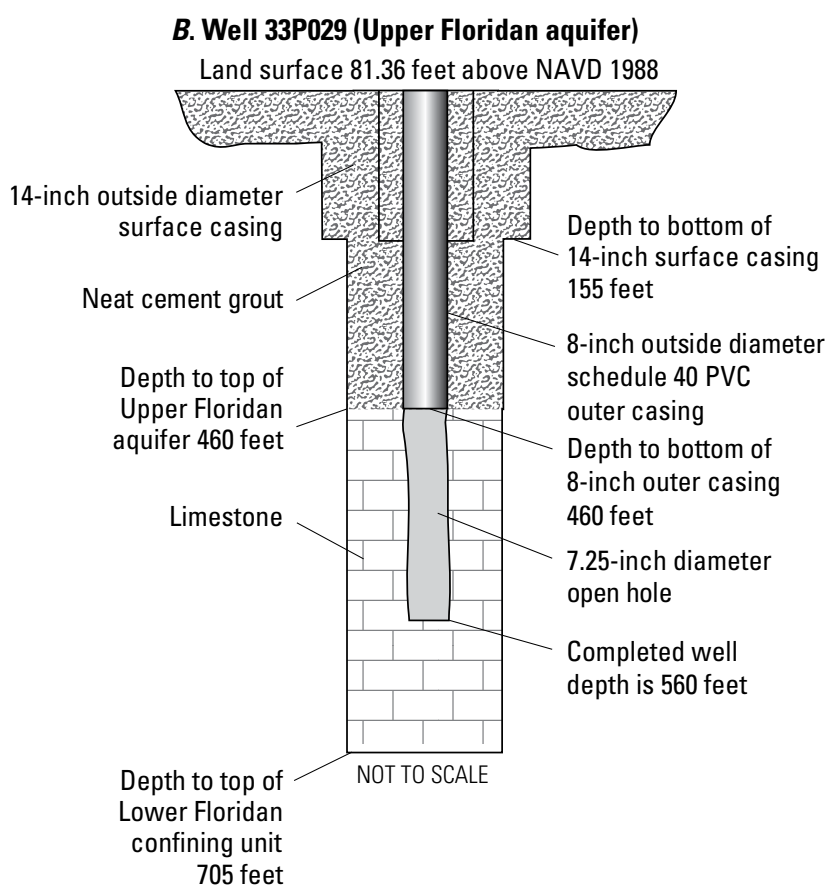

Figure 3. Well-construction diagrams for $(A)$ well 33P028 and (B) well 33P029 at Fort Stewart, GA, 2010 (John S. Clarke, U.S. Geological Survey, written commun., January 2011). 


\section{Methods of Study}

Hydraulic characteristics of the Floridan aquifer system at Fort Stewart, GA, were determined by installing two wells and performing geophysical logging, flowmeter surveys, slug tests, aquifer tests, and analyses. Method details concerning drilling and well construction, geophysical logging, flowmeter surveys, and hydrologic testing are described below.

\section{Drilling, Core Collection, and Well Construction}

An initial borehole was drilled to $1,300 \mathrm{ft}$ during midNovember 2009 and cased to near the top of the Floridan aquifer system at a depth of $460 \mathrm{ft}$ below land surface (fig. 3). Drill cores were collected at four discrete depths within the Lower Floridan confining unit and tested for vertical hydraulic conductivity and porosity using standard laboratory methods. Geophysical logs and flowmeter surveys were conducted during late November 2009 in the carbonate deposits of the borehole from 460 to $1,300 \mathrm{ft}$. Slug tests were completed at four packer-isolated intervals in the Lower Floridan confining unit in early December 2009. Borehole 33P028 was completed to a depth of $1,255 \mathrm{ft}$ in mid-January 2010 as well 33P028 in the Lower Floridan aquifer. A 14-inch diameter carbonsteel casing was installed to a depth of $895 \mathrm{ft}$, and the well was completed as a 12.25-inch open hole in limestone. The borehole was backfilled in the 1,255 to 1,300-ft interval with a bentonite-grout mixture. Water-level monitoring began in well 33P028 on January 27, 2010.

Well 33P029 in the Upper Floridan aquifer was constructed $40 \mathrm{ft}$ southwest of well 33P028 in mid-February 2010 (fig. 3). The casing was 8 -inch diameter schedule 40 polyvinyl chloride (PVC) installed to a depth of $460 \mathrm{ft}$, and the well was completed as a 7.25-inch open hole in limestone. Water-level monitoring began in well 33P029 in the Upper Floridan aquifer on February 24, 2010, and in a previously installed well (33P025) on February 25, 2010. Background wells 33M004 and 34N089 have been monitored for water levels for years prior to the study.

\section{Geophysical Logs, Flowmeter Surveys, and Hydraulic Properties from Wells}

Borehole geophysical logs were collected at various stages of drilling to characterize the physical properties of the sediments penetrated (fig. 4). Borehole geophysical logs include caliper, natural gamma, spontaneous potential, lateral long-normal (64-inch) and short-normal (16-inch) resistivity, borehole fluid resistivity, and temperature. Not shown in this report but also collected were single-point resistivity, fullwaveform sonic acoustic televiewer, and optical televiewer logs.

Flowmeter surveys were used to determine the relative contribution of flow from water-bearing zones and confinement between the Upper and Lower Floridan aquifers (fig. 5). Surveys were conducted by installing a test pump in the well and pumping while several traverses were made in the open borehole with an electromagnetic (EM) flowmeter to measure accumulated flow up the borehole. This information ensured accurate placement of the well casing in the completed well. The EM flowmeter surveys were conducted in two stages. The first was conducted during November 19-20, 2009, upon completion of drilling to a total depth of $1,300 \mathrm{ft}$, and prior to installing the 14-inch casing, to test flow in the 460- to 1,300-ft interval (Upper and Lower Floridan aquifers, fig. $5 A$ ). The second survey was conducted on January 26, 2010, after installing the 14-inch casing, to test flow in the 895- to 1,300$\mathrm{ft}$ interval (Lower Floridan aquifer only, fig. 5B). The first stage included assessment of borehole flow at a pumping rate of 770 gallons per minute (gal/min); during the second stage, borehole flow was measured at a pumping rate of $740 \mathrm{gal} / \mathrm{min}$.

Horizontal hydraulic conductivity estimates of the Lower Floridan confining unit were obtained by performing slug tests at four depth intervals $(726.5-733.5 \mathrm{ft}, 766.5-773.5 \mathrm{ft}$, $816.5-823.5 \mathrm{ft}$, and $876.5-883.5 \mathrm{ft}$ ). Special simulations of slug-test water levels were made to account for the effects of prolonged slug events. Concepts from Bouwer and Rice (1976) were used to determine hydraulic conductivity of three of the intervals, and the van der Kamp (1976) method was used in the other because of higher permeability and an oscillatory water-level response. More detail on testing and analytical procedures for the slug tests is provided in a subsequent section of this report.

Aquifer tests were conducted to estimate the transmissivity of the Upper and Lower Floridan aquifers and to determine the effects of pumping one aquifer on water levels in the other aquifer. For each test, water levels were monitored in the pumping well and in two observation wells. Each of three wells was instrumented with a vented transducer. Transducer measurements are recorded as feet of water above the probe and were transformed to show depth to water below land surface. Drawdown for the three monitored wells was estimated by using a procedure developed by Halford (2006a) to filter water-level data for effects of barometric pressure, earth tide, and long-term trends.

A 24-hour aquifer test was performed in the Upper Floridan aquifer well 33P029 during March 3-4, 2010, with the well pumping at an average rate of $387 \mathrm{gal} / \mathrm{min}$. The Cooper-Jacob, straight-line method (Cooper and Jacob, 1946) was applied to the drawdown data from this well to determine the transmissivity of the Upper Floridan aquifer.

A 72-hour aquifer test was performed in the Lower Floridan aquifer well 33P028 during March 8-11, 2010, when the well was pumped at an average rate of $740 \mathrm{gal} / \mathrm{min}$. Transmissivity of the Upper and Lower Floridan aquifers was estimated by using the numerical model MODFLOW-96 (McDonald and Harbaugh, 1988; Harbaugh and McDonald, 1996) with the calibration tool MODOPTIM (Halford, 2006b). A more complete description of the 24- and 72-hour aquifer tests and analytical procedures is provided in subsequent sections of the report. 


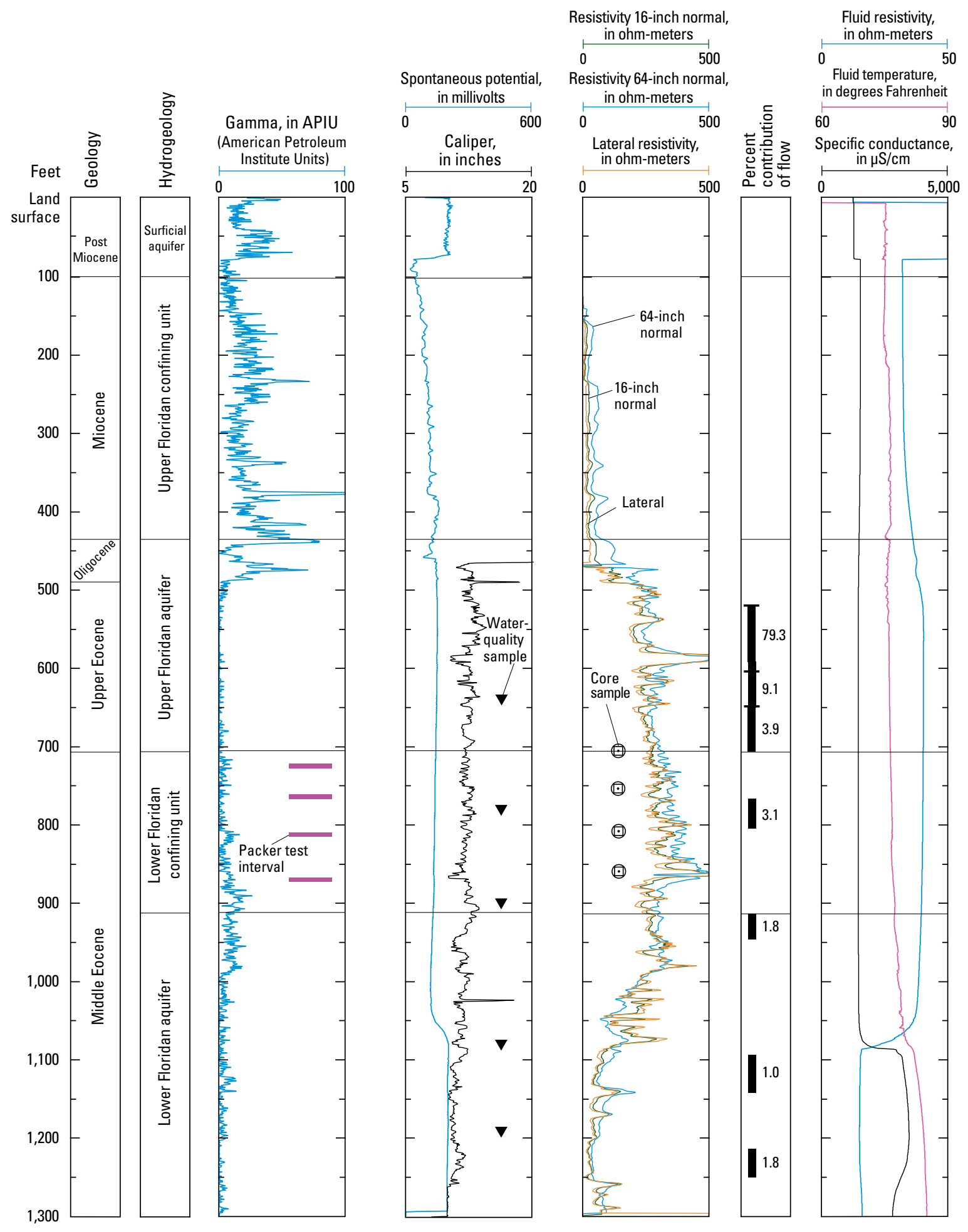

Figure 4. Selected borehole geophysical data and percent flow contribution from permeable zones in borehole 33P028, 460-1,300 feet at Fort Stewart, GA, 2010. Percent flow contribution was determined from flowmeter survey in borehole 33P028 (see fig. $5 A$; John S. Clarke, U.S. Geological Survey, written commun., January 2011). [ $\mu \mathrm{S} / \mathrm{cm}$, microsiemens per centimeter at 25 degrees Celsius] 


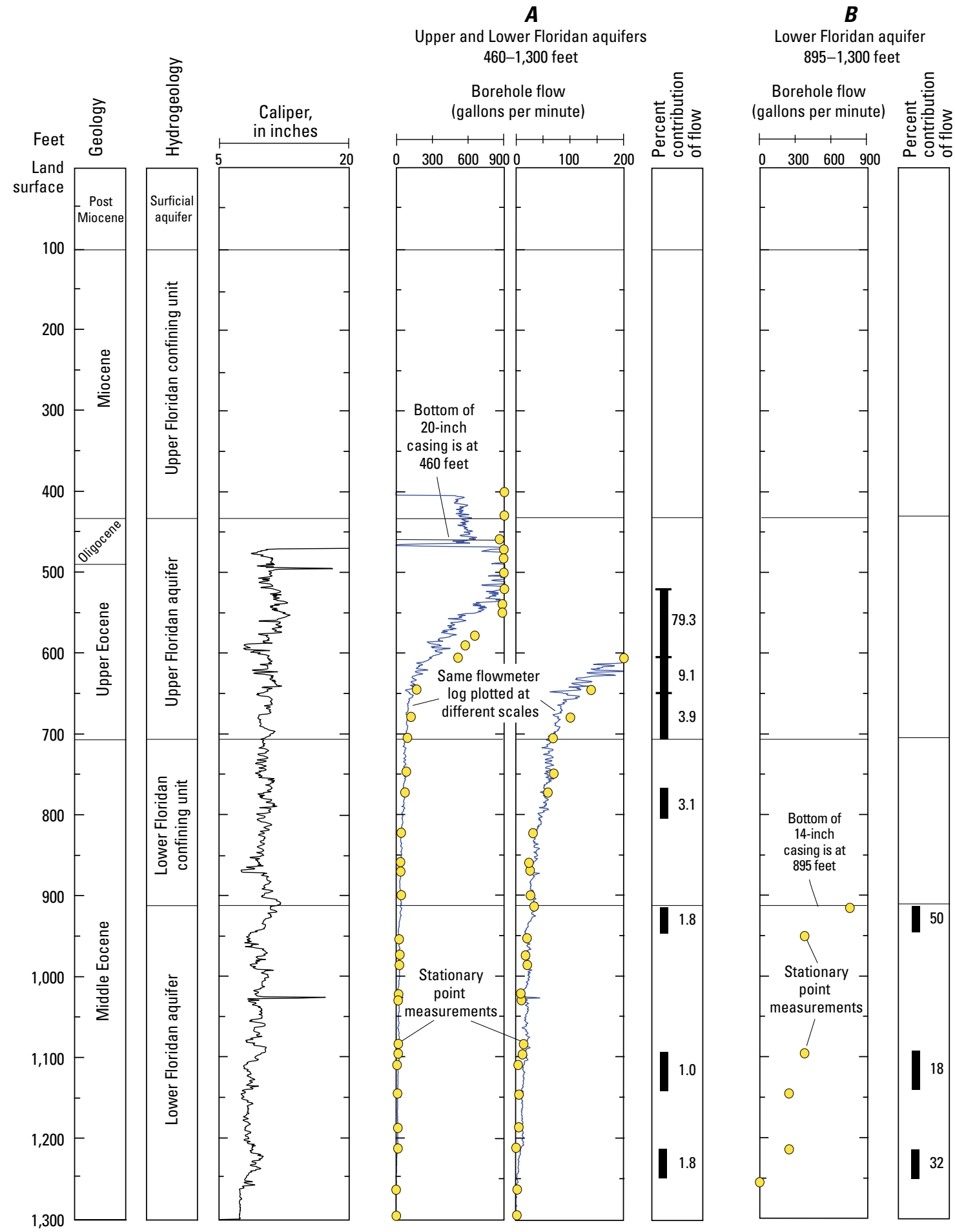

Figure 5. Flowmeter survey data from $(A)$ pumping the Upper and Lower Floridan aquifers prior to installing a 14-inch casing in borehole 33P028, and $(B)$ pumping the Lower Floridan aquifer after installing a 14-inch casing in borehole 33P028 and completing it as well 33P028 at Fort Stewart, GA (John S. Clarke, U.S. Geological Survey, written commun., January 2011). 


\section{Hydrologic Testing}

Geophysical logs and flowmeter surveys at borehole 33P028 delineate several water-bearing zones bounded by less-permeable zones throughout the Floridan aquifer system (John S. Clarke, USGS, written commun., September 13, 2010). The Upper Floridan aquifer occurs at depths between 440 and $705 \mathrm{ft}$ and is composed of two water-bearing zones - the 520 - to $650-\mathrm{ft}$ upper zone, which is more permeable than the 650 - to $705-\mathrm{ft}$ lower zone (figs. 4, 5). Flowmeter surveys indicate that the upper zone contributes 96 percent of the flow in the Upper Floridan aquifer; the lower zone contributes the remaining 4 percent (fig. 5).

At borehole 33P028 is a unit that is mapped by Williams and Gill (2010) as the Lower Floridan confining unit. Hydrologic properties of this unit, however, are similar to those of the Lower Floridan aquifer as described later. For discussion in this report, this mapped hydrogeologic unit will be referred to as the Lower Floridan confining unit.

The Lower Floridan confining unit extends from the base of the Upper Floridan to about a depth of $912 \mathrm{ft}$ and is composed of three zones; the middle zone is much more permeable than the top and bottom zones. The middle permeable, relatively high-yielding zone of the Lower Floridan confining unit extends at depths from 793 to $822 \mathrm{ft}$ (fig. 5). Drill cores were collected within the Lower Floridan confining unit and tested for vertical hydraulic conductivity and porosity. Laboratory tests of cores at depths from 703 to $855 \mathrm{ft}$ indicate vertical hydraulic conductivities ranging from 0.26 to $0.79 \mathrm{ft}$ per day (ft/d) and porosities ranging from 0.25 to 0.38 (table 2).

The Lower Floridan aquifer extends from the base of the Lower Floridan confining unit to at least a depth of $1,300 \mathrm{ft}$ and contains three permeable zones- $-912-947 \mathrm{ft}$, 1,090-1,139 ft, and 1,211-1,250 ft-interlayered with three less-permeable zones. Abnormally high water temperatures in the bottom $200 \mathrm{ft}$ of the borehole (fig. 4) indicate the possibility of upward flow from deeper units (John S. Clarke, U.S. Geological Survey, written commun., September 13, 2010).

Table 2. Estimated vertical hydraulic conductivity and porosity of core samples collected from the Lower Floridan confining unit in borehole 33P028 at Fort Stewart, GA.

[Analyses by Geotechnics, Inc., East Pittsburgh, PA]

\begin{tabular}{ccc}
\hline $\begin{array}{c}\text { Core sample } \\
\text { interval } \\
\text { (feet below } \\
\text { land surface) }\end{array}$ & $\begin{array}{c}\text { Vertical hydraulic } \\
\text { conductivity } \\
\text { (feet per day) }\end{array}$ & Porosity \\
\hline $702.9-703.8$ & 0.26 & 0.37 \\
$750.9-751.4$ & 0.37 & 0.25 \\
$803.5-804.4$ & 0.40 & 0.26 \\
$854.0-854.8$ & 0.79 & 0.38 \\
Average & 0.45 & 0.32 \\
\hline
\end{tabular}

\section{Slug Tests}

Horizontal hydraulic conductivity estimates of the Lower Floridan confining unit were obtained by conducting slug tests within four packer-isolated intervals in borehole 33P028 at depths of $726.5-733.5 \mathrm{ft}, 766.5-773.5 \mathrm{ft}, 816.5-823.5 \mathrm{ft}$, and 876.5-883.5 ft during December 5-6, 2009 (fig. 4; table 3). Two slug tests were conducted for each interval. Each interval was isolated by first using straddle packers and then injecting a slug of water, usually 10 gallons in volume, into the $7-\mathrm{ft}$ interval through a 3 -inch diameter pipe. The change in head over time was recorded. Pressure transducers were used to monitor water-level response within the isolated interval as well as above and below the zone being tested. The general procedures for conducting these tests were as follows:

1. Lower packer assembly to the target depth.

2. Attach pressure transducers to dataloggers and start recording at 1 -second intervals.

3. Inflate upper packer to full seating pressure.

4. Inflate lower packer to full seating pressure.

5. Allow water level in the test interval to stabilize (typically 10 minutes).

6. Inject water into the isolated interval through the drill stem to raise water level within the test interval.

7. Monitor water level before, during, and after injection until water levels return to pre-test conditions.

8. Review pressure data from above and below the isolated interval to check for indications of leakage across the straddle packer; re-inflate or reposition packers if necessary.

9. Deflate packers and move to the next depth interval.

The caliper log was used to position the packers in smooth sections of the borehole that were selected to be more likely to have the greatest potential for good packer seating. Vugs, solution cavities, and irregular borehole enlargements were identified so the rubber packers would not be inflated along these irregular surfaces. Data from upper and lower pressure transducers indicated that the packers adequately sealed the test intervals.

A normal slug test involves the nearly instant insertion or withdrawal of a slug to or from the water column. The period of the slug event is very brief and the ensuing recovery is then related to the hydraulic conductivity of the surrounding aquifer material. Peak water level as discussed in this report is the highest water level attained during the insertion of slug water.

In this study, complete placement of water into the water column for the slug test (hereafter referred to as the slug event) took at least 15 to 30 seconds. This conservative estimate of the duration of the slug event is based on a 
Table 3. Slug times for packer-isolated intervals in borehole 33P028 at Fort Stewart, GA, December 5-6, 2009.

$[\mathrm{Pk} / 90 \mathrm{r}$, the ratio of time for the water level to rise to peak $(\mathrm{Pk})$ water level to the 90 -percent recovery time (90r) after peak water level; *, slug recovery oscillates, time in seconds for 90-percent damping of oscillation amplitude]

\begin{tabular}{|c|c|c|c|c|c|c|}
\hline \multirow{2}{*}{$\begin{array}{c}\text { Packer-isolated } \\
\text { interval } \\
\text { (feet below } \\
\text { land surface) }\end{array}$} & \multirow[b]{2}{*}{ Test } & \multicolumn{2}{|c|}{ Start of slug test } & \multirow{2}{*}{$\begin{array}{l}\text { Time for } \\
\text { water to rise } \\
\text { to peak } \\
\text { (seconds) }\end{array}$} & \multirow{2}{*}{$\begin{array}{l}90 \text {-percent } \\
\text { recovery } \\
\text { after peak } \\
\text { (seconds) }\end{array}$} & \multirow[b]{2}{*}{$\mathrm{Pk} / 90 \mathrm{r}$} \\
\hline & & $\begin{array}{c}\text { Date } \\
\text { (2009) }\end{array}$ & $\begin{array}{l}\text { Time } \\
\text { (EST) }\end{array}$ & & & \\
\hline \multirow[t]{2}{*}{$726.5-733.5$} & 1 & Dec 05 & $17: 03: 31$ & 30 & 53 & 0.57 \\
\hline & 2 & Dec 05 & 17:33:06 & 18 & 44 & 0.41 \\
\hline \multirow[t]{2}{*}{$766.5-773.5$} & 1 & Dec 06 & $9: 37: 23$ & 15 & $32 *$ & 0.47 \\
\hline & 2 & Dec 06 & 9:58:09 & 17 & $38^{*}$ & 0.45 \\
\hline \multirow[t]{2}{*}{$816.5-823.5$} & 1 & Dec 06 & $11: 32: 27$ & 16 & 41 & 0.39 \\
\hline & 2 & Dec 06 & $11: 43: 41$ & 20 & 39 & 0.51 \\
\hline \multirow[t]{2}{*}{$876.5-883.5$} & 1 & Dec 06 & $13: 16: 10$ & 19 & 358 & 0.05 \\
\hline & 2 & Dec 06 & $13: 36: 56$ & 23 & 379 & 0.06 \\
\hline
\end{tabular}

gradual increase in water levels to a peak water level resulting from the slug event (table 3 ). These prolonged slug events complicated the determination of hydraulic conductivity of the surrounding aquifer material, because of ongoing water-level recovery. At some point during the slug test, water was still entering the water column in the well, but at a rate that was less than the recovery rate. As a result, part of the recession curve represents the recovery being slowed down by the continued insertion of water during the slug event. This part of the recession could not be evaluated for hydraulic conductivity using standard techniques. The actual time that this type of recession occurred initially was not known.

To account for the effect of the prolonged slug events, slug-test water levels of the three packer-isolated intervals through time were simulated. Another packer-isolated interval could not be simulated due to its response (discussed later). The simulation involved injecting water into the water column on a per-second basis. While water was being injected, a recovery constant was applied to the water column in the well to control the rate of recovery. By calibrating a simulation to the measured water levels of a slug test, two key pieces of information were obtained: (1) the recovery constant used for successful calibration that can be used to determine the hydraulic conductivity of the surrounding aquifer material, and (2) simulated water injection for successful calibration can be used to determine when the slug event was complete. Once the completion of the slug event is known, based on the results of the simulation, the recovery curve can be used in standard analysis to determine the hydraulic conductivity of the surrounding aquifer material. The value determined from standard analysis can be compared with that derived from the simulation. The following equation governs the slug-test simulation:
$H_{(t)}=H_{(f)}+\frac{\left(H_{(t-1)}+I_{(t-1)}-H_{(f)}\right)}{e^{m(\Delta t)}}$,

where

$$
\begin{gathered}
H_{(t)} \quad \begin{array}{l}
\text { is the simulated water level at time } t \text {, in feet; } \\
H_{(f)}
\end{array} \text { is the final water level, which is the same } \\
\text { as the stable or background water level } \\
\text { because the duration of the slug tests are } \\
\text { on the order of minutes, in feet; } \\
\text { is the simulated water level at time } t-1, \\
\text { in feet; } \\
H_{(t-1)} \\
I_{(t-1)} \quad \begin{array}{l}
\text { is the simulated volume of slug water that } \\
\text { connects to and is injected into the water } \\
\text { column in the well casing at time } t-1, \\
\text { in feet; }
\end{array} \\
\text { is the decay constant for the difference } \\
\text { between } H_{(t-1)} \text { and } H_{(f)} \text {, in seconds }{ }^{-1} \text {; and } \\
m^{\prime} \quad \text { is the amount of time between time } t \text { and }
\end{gathered}
$$$$
\text { time } t-1 \text { or } 1 \text { second. }
$$

Figures presented in this report set the $H_{(f)}$ to zero.

Simulated water levels had a very close fit to measured water levels in the three packer-isolated intervals. Also, the total simulated injection volumes were closer to the reported slug volumes than estimated volumes based on peak water levels times the area of the casing cross section (table 4).

The decay constant $m^{\prime}$ used to match the simulated water levels to the measured water levels, physical dimensions of the packer-isolated interval, and concepts from Bouwer and Rice (1976) were then used to determine the hydraulic conductivity of the packer-isolated interval (table 5). From Bouwer and Rice (1976) and equation 1: 
Table 4. Total injection volume and test-specific values for parameters used with the Bouwer and Rice (1976) method to estimate hydraulic conductivity.

[Inner diameter of casing is 3 inches]

\begin{tabular}{|c|c|c|c|c|c|c|c|}
\hline \multirow[b]{2}{*}{$\begin{array}{l}\text { Packer-isolated } \\
\text { interval } \\
\text { (feet below } \\
\text { land surface) }\end{array}$} & \multirow[b]{2}{*}{ Test } & \multicolumn{3}{|c|}{ Total injection volume (gallons) } & \multirow[b]{2}{*}{$\begin{array}{l}\text { Peak } \\
\text { water } \\
\text { level } \\
\text { (feet) }\end{array}$} & \multicolumn{2}{|c|}{ Test-specific values } \\
\hline & & Reported & $\begin{array}{l}\text { Estimated } \\
\text { from } \\
\text { simulation }\end{array}$ & $\begin{array}{c}\text { Estimated from } \\
\text { peak water } \\
\text { level }\end{array}$ & & $\begin{array}{c}\text { Well-bore } \\
\text { radius } \\
r_{w} \\
\text { (feet) }\end{array}$ & $\begin{array}{c}\text { Decay } \\
\text { constant } \\
\mathbf{m}^{\prime} \\
\left(\mathrm{sec}^{-1}\right)\end{array}$ \\
\hline \multirow[t]{2}{*}{$726.5-733.5$} & 1 & 5 & 2.3 & 1.1 & 2.96 & 0.508 & 0.048 \\
\hline & 2 & 10 & 3.4 & 2.3 & 6.38 & 0.508 & 0.052 \\
\hline \multirow[t]{2}{*}{$816.5-823.5$} & 1 & 10 & 2.9 & 1.8 & 5.00 & 0.492 & 0.062 \\
\hline & 2 & 10 & 3.7 & 2.2 & 5.86 & 0.492 & 0.062 \\
\hline \multirow[t]{2}{*}{$876.5-883.5$} & 1 & 10 & 4.2 & 3.9 & 10.56 & 0.517 & 0.0068 \\
\hline & 2 & 10 & 4.1 & 3.8 & 10.35 & 0.517 & 0.0067 \\
\hline
\end{tabular}

Table 5. Hydraulic conductivity values for packer-isolated intervals in borehole 33P028 in the Lower Floridan confining unit at Fort Stewart, GA, December 5-6, 2009.

[ft/d, feet per day; HSBR, values determined using the Halford and Kuniansky (2002) spreadsheet based on Bouwer and Rice (1976); MSBR, values determined using the decay constant that matched simulated water levels to measured water levels, physical dimensions of the packer-isolated interval, and concepts from Bouwer and Rice (1976); HVDK, values determined using the Halford and Kuniansky (2002) spreadsheet based on van der Kamp (1976); - , not applicable]

\begin{tabular}{|c|c|c|c|c|c|c|c|}
\hline \multirow{2}{*}{$\begin{array}{c}\text { Packer-isolated } \\
\text { interval } \\
\text { (feet below } \\
\text { land surface) }\end{array}$} & \multicolumn{3}{|c|}{ Test 1-Hydraulic conductivity (ft/d) } & \multicolumn{3}{|c|}{ Test 2-Hydraulic conductivity (ft/d) } & \multirow{2}{*}{$\begin{array}{c}\text { Final } \\
\text { values } \\
\text { (ft/d) }\end{array}$} \\
\hline & HSBR & MSBR & HVDK & HSBR & MSBR & HVDK & \\
\hline $726.5-733.5$ & 18.8 & 18.2 & - & 20.5 & 19.7 & - & 20 \\
\hline $766.5-773.5$ & - & - & 65.0 & - & - & 74.3 & 70 \\
\hline $816.5-823.5$ & 24.2 & 23.7 & - & 23.5 & 23.9 & - & 20 \\
\hline $876.5-883.5$ & 2.3 & 2.6 & - & 2.3 & 2.6 & - & 2 \\
\hline
\end{tabular}

$$
K=\frac{m^{\prime} 86,400 r_{c}^{2} \ln \left[\frac{R_{e}}{r_{w}}\right]}{2 L},
$$

where

$K \quad$ is the hydraulic conductivity, in feet per day;

$r_{c} \quad$ is the radius of the well casing where the water-level change occurs, $0.0625 \mathrm{ft}$;

$R_{e} \quad$ is the effective radial distance from the well over which the head difference is dissipated, in feet;

$r_{w} \quad$ is the radial extent of the well to the undisturbed material (borehole radius), between 0.491 and $0.517 \mathrm{ft}$;

$L \quad$ is the length of the packer-isolated interval open to the material, $7 \mathrm{ft}$; and $m^{\prime} \quad$ is the decay constant, in seconds ${ }^{-1}$, used to fit simulated water levels to measured water levels.

Values of $\ln \left(R_{e} / r_{w}\right)$ are determined assuming full penetration of the aquifer (minimal vertical groundwater movement). The $r_{w}$ and $m^{\prime}$ values for each test are listed in table 4 .

When the simulation indicated the slug event was completed, the water-level recovery known to be after the slug event was used in a spreadsheet from Halford and Kuniansky (2002) based on the Bouwer and Rice (1976) method to determine the hydraulic conductivity of the surrounding aquifer material (table 5). For intervals $726.5-733.5 \mathrm{ft}, 816.5-823.5 \mathrm{ft}$, and $876.5-883.5 \mathrm{ft}, K$ values resulting from the simulation were essentially the same as those from the Halford and Kuniansky (2002) spreadsheet based on the Bouwer and Rice (1976) method. 


\section{Test Results at the 726.5- to 733.5-Foot Interval}

Water levels in two slug tests in the first packer-isolated interval in well 33P028 at $726.5-733.5 \mathrm{ft}$ were evaluated by using the Bouwer and Rice (1976) method (fig. 6; tables 3-5). The initial water level was $78.10 \mathrm{ft}$ below land surface. For the first test, a 5-gallon slug of water was introduced into the packer-isolated interval through the 3 -inch diameter drill stem. Water injection took at least 30 seconds to enter the packerisolated interval based on the time water levels rose to a peak. The peak water level was $2.96 \mathrm{ft}$, and 90-percent recovery after peak was reached after 53 seconds. For the second test, a 10-gallon slug of water was injected over a period of at least 18 seconds. The peak water level was $6.38 \mathrm{ft}$, and 90 -percent recovery after peak was reached after 44 seconds.

Simulated water levels were a close fit to measured water levels for both tests (fig. 6). Simulation results indicate that the water injection for tests 1 and 2 took 39 and 21 seconds, respectively. Total simulated volume of water injected for tests 1 and 2 was 2.3 and 3.4 gallons, respectively. Results of both tests indicated a hydraulic conductivity of about $20 \mathrm{ft} / \mathrm{d}$ (table 5).

\section{Test Results at the 766.5- to 773.5-Foot Interval}

Slug tests for the 766.5- to 773.5-ft packer-isolated interval were characterized by an oscillatory response indicative of high permeability (fig. 7; table 3). Before tests 1 and 2, water levels were 77.88 and $78.08 \mathrm{ft}$ below land surface, respectively. For each test, a 10-gallon slug of water was injected into the packer-isolated interval through the 3 -inch diameter drill stem. Water injection for tests 1 and 2 took at least 15 and 17 seconds, respectively, to enter the packerisolated interval. The peak water levels for tests 1 and 2 were 4.97 and $5.10 \mathrm{ft}$, respectively. The response for both tests was slightly underdamped (oscillating water levels, fig. 7). Tests 1 and 2 initially recovered from peak water levels to pre-test water levels in 15 and 17 seconds, respectively. Following this initial recovery, water levels for tests 1 and 2 declined 0.20 and $0.17 \mathrm{ft}$ beneath pre-test water levels, respectively. Water levels for tests 1 and 2 then swung back up to a second peak of about 0.08 and $0.19 \mathrm{ft}$, respectively, about 40 seconds after the first peak in water levels. Following these oscillations, water levels finally stabilized roughly 80 seconds after the initial peak water level.

Because of the water-level oscillations that occurred at this interval, the van der Kamp (1976) method was used to determine hydraulic conductivity. An underdamped response typically has an oscillation of a constant frequency that decreases in amplitude over time with the rate of decrease being constant. A spreadsheet from Halford and Kuniansky (2002) based on van der Kamp (1976) was used to analyze the data for Transmissivity. A 5-point moving average was used in the water-level data to reduce noise. With an assumed storativity of $2.15 \mathrm{E}-05$, (based on results of 72-hour aquifertest model), results of both slug tests within this isolated interval indicate a hydraulic conductivity of approximately $70 \mathrm{ft} / \mathrm{d}$ (figs. 8, 9; table 5). The estimates are not very accurate because the water-level oscillation barely completed one full cycle before stabilizing, precluding the use of several peaks to accurately determine the damping coefficent.

\section{Test Results at the 816.5- to 823.5-Foot Interval}

Water levels in two slug tests in the third packer-isolated interval in well 33P028 at $816.5-823.5 \mathrm{ft}$ were evaluated by using the Bouwer and Rice (1976) method (fig. 10; tables 3-5). Initial water levels before tests 1 and 2 were 77.98 and $78.02 \mathrm{ft}$ below land surface, respectively. To initiate each test, a 10 -gallon slug of water was injected into the packer-isolated interval through the 3 -inch diameter drill stem. Water injection for tests 1 and 2 took at least 16 and 20 seconds, respectively, to enter the interval. The peak water levels for tests 1 and 2 were 5.00 and $5.86 \mathrm{ft}$, respectively. After peak water levels were achieved, 90-percent recovery for tests 1 and 2 was reached at 41 and 39 seconds, respectively.

Simulated water levels were a close fit to measured water levels (fig. 10). Model results indicate that the water injections for tests 1 and 2 took 24 and 26 seconds, respectively. Total volume of injected water for tests 1 and 2 was estimated at 2.9 and 3.7 gal, respectively (table 4). Results of both tests indicated a hydraulic conductivity of about $20 \mathrm{ft} / \mathrm{d}$ (table 5).

\section{Test Results at the 876.5- to 883.5-Foot Interval}

Water levels in two slug tests in the fourth packer-isolated interval at $876.5-883.5 \mathrm{ft}$ in well $33 \mathrm{P} 028$ were evaluated by using the Bouwer and Rice (1976) method (fig. 11; tables 3-5). Water levels before tests 1 and 2 were 77.03 and $77.15 \mathrm{ft}$ below land surface, respectively. To initiate each test, a 10-gallon slug of water was injected into the packer-isolated interval through the 3 -inch diameter drill stem. Water injection for tests 1 and 2 took at least 19 and 23 seconds to enter the packer-isolated interval, respectively. The peak water levels for tests 1 and 2 were 10.56 and $10.35 \mathrm{ft}$, respectively. After peak water levels were achieved, 90-percent recovery for tests 1 and 2 was reached 5 minutes 58 seconds and 6 minutes 19 seconds, respectively.

Simulated water levels were a close fit to measured water levels (fig. 11). Model results indicate that the water injection for tests 1 and 2 took 25 and 23 seconds, respectively. Total volume of water injected for tests 1 and 2 was estimated at 4.2 and 4.1 gal, respectively. Results of both tests indicated a hydraulic conductivity of about $2 \mathrm{ft} / \mathrm{d}$, the lowest of the four intervals tested (table 5). 


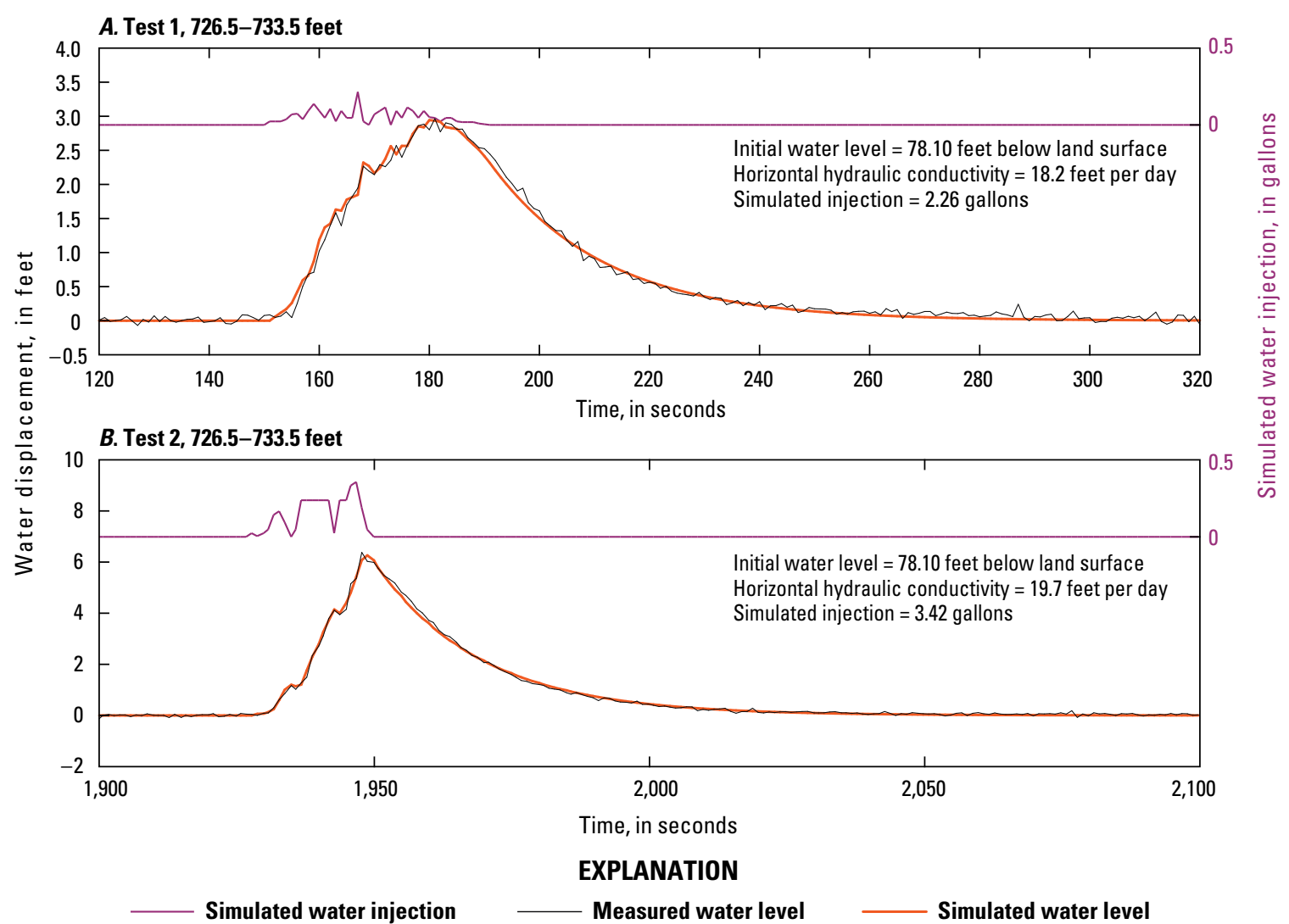

Figure 6. Measured and simulated water levels and simulated water-injection volumes for packer-isolated interval 726.5- to 733.5-feet in borehole 33P028 at Fort Stewart, GA, December 5, 2009. Both tests roughly yield a hydraulic conductivity of 20 feet per day. $(A)$ Test 1, 5-gallon slug test, $(B)$ Test 2, 10-gallon slug test.

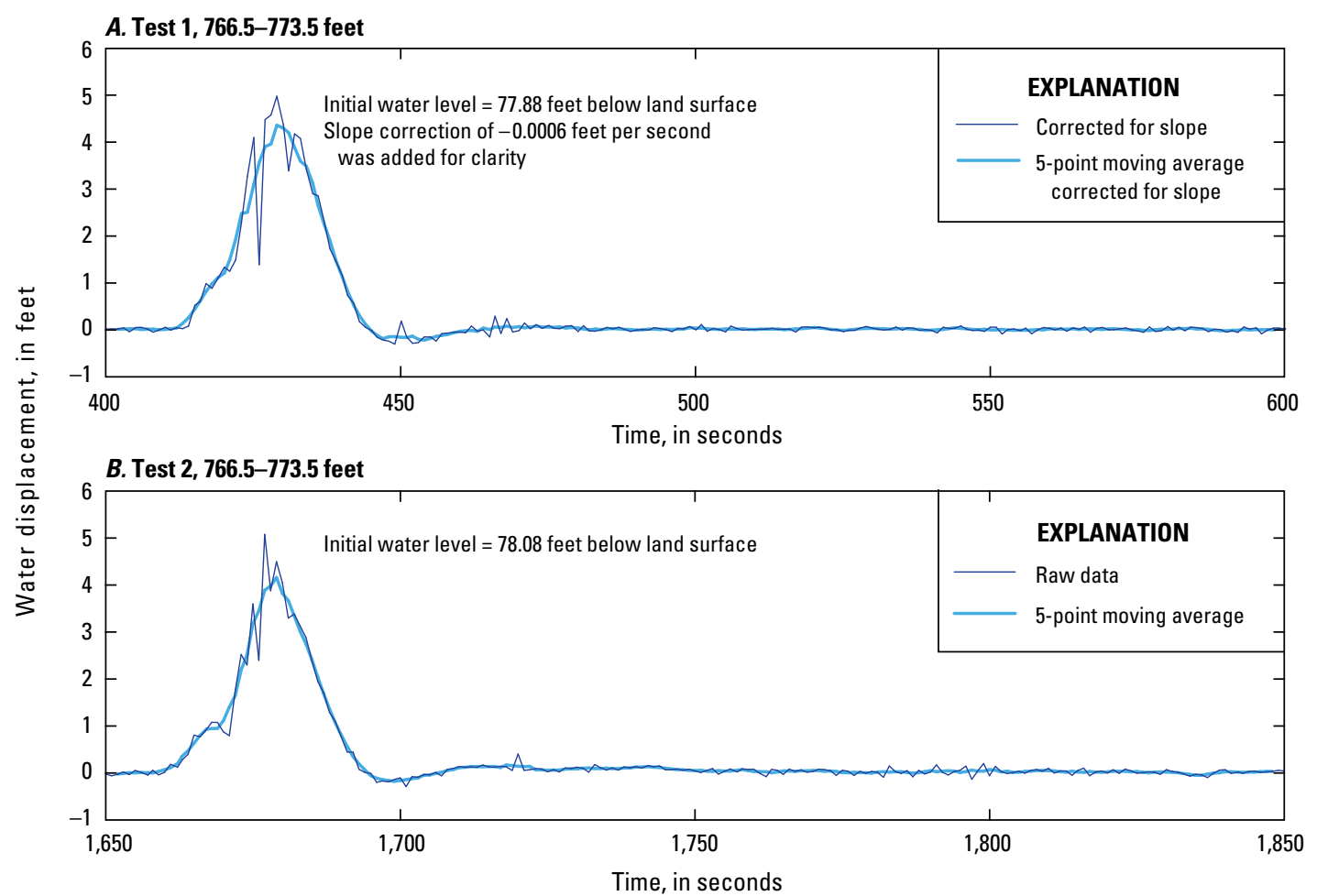

Figure 7. Slightly underdamped water-level responses to a 10-gallon slug of water injected into packer-isolated interval 766.5- to 773.5-feet in borehole 33P028 at Fort Stewart, GA, December 6, 2009. 

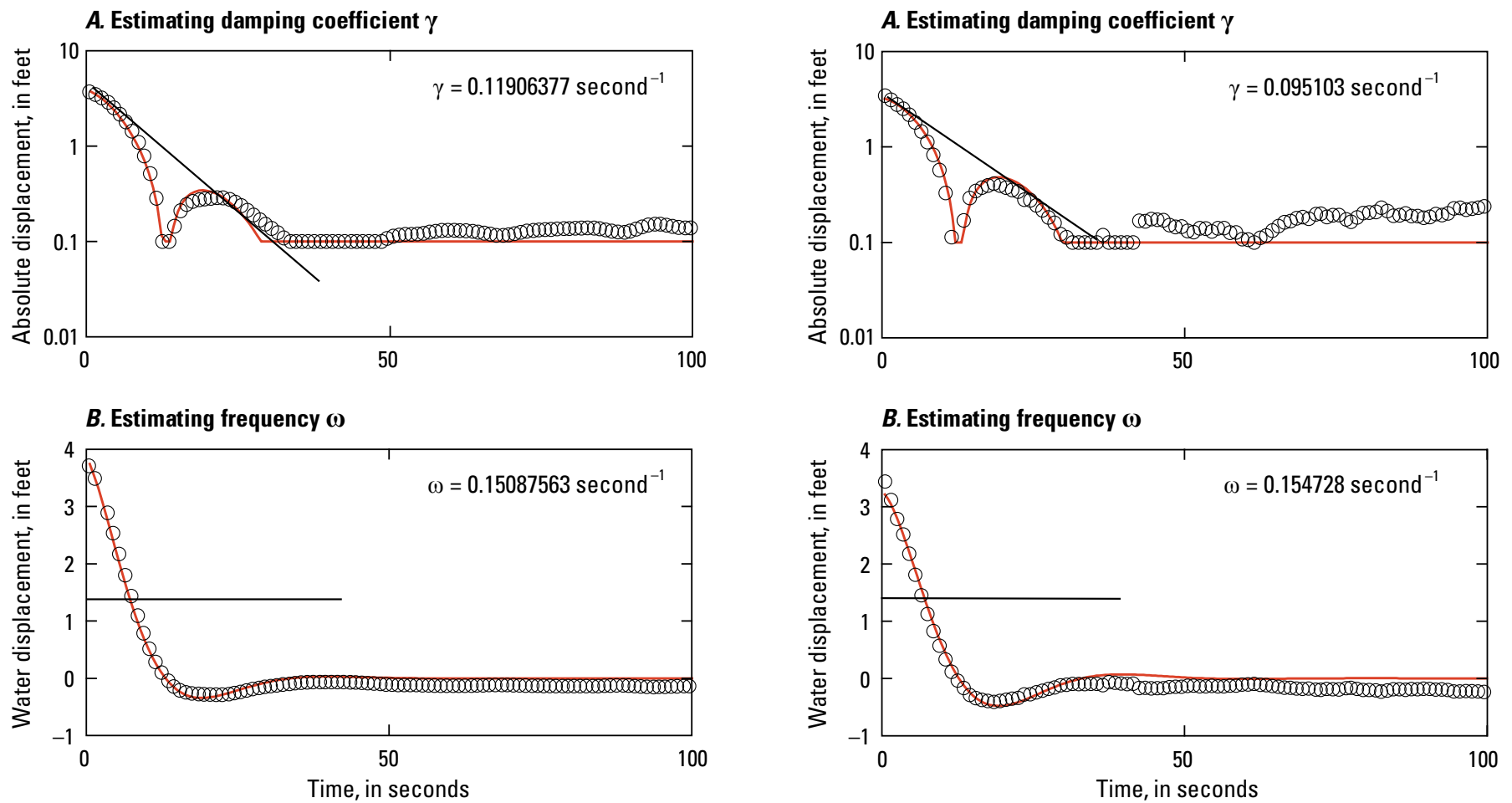

\section{EXPLANATION}

\section{EXPLANATION}
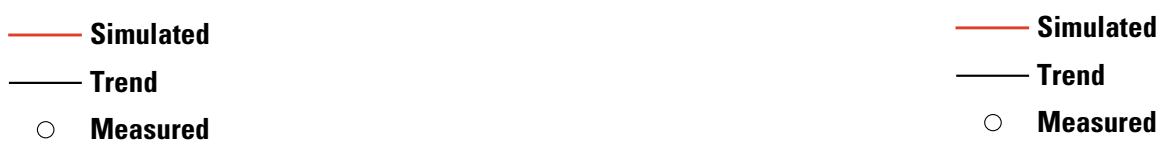

Figure 8. Measured and simulated water levels for test 1 in the packer-isolated interval 766.5- to 773.5-feet in borehole 33P028 at Fort Stewart, GA, December 6, 2009. (A) Log of absolute value of displacement as a function of time, used to determine damping coefficient $\gamma,(B)$ Water displacement as a function of time, used to determine oscillation frequency $\omega$. Simulation is based on van der Kamp (1976) method. Graphs are modified from spreadsheet from Halford and Kuniansky (2002). 


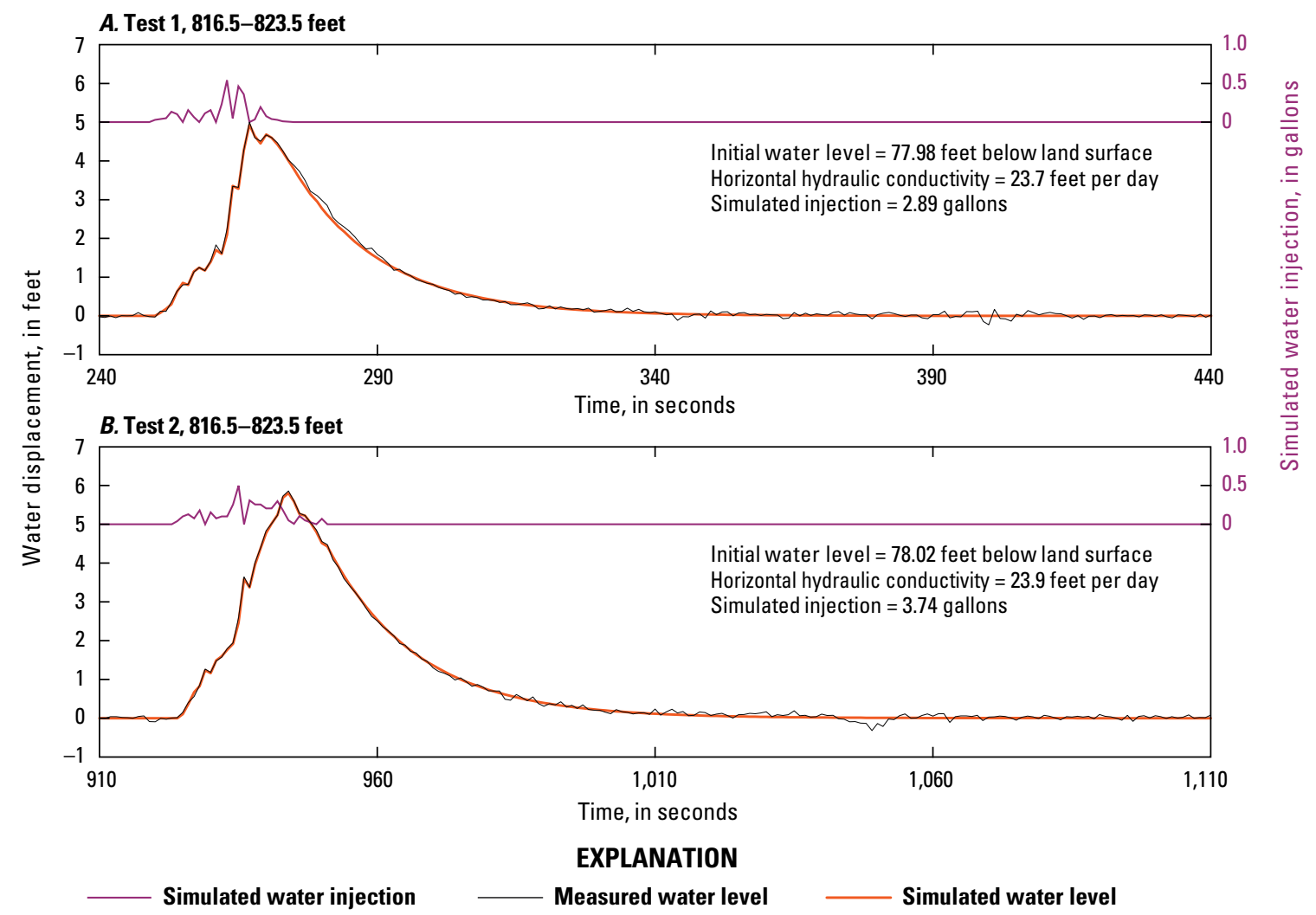

Figure 10. Measured and simulated water levels and simulated injection of water for packer-isolated interval 816.5- to 823.5-feet in borehole 33P028 at Fort Stewart, GA, December 6, 2009. Both tests were reported to be 10-gallon slug tests and both roughly yielded a hydraulic conductivity of 20 feet per day. (A) Test 1, (B) Test 2.

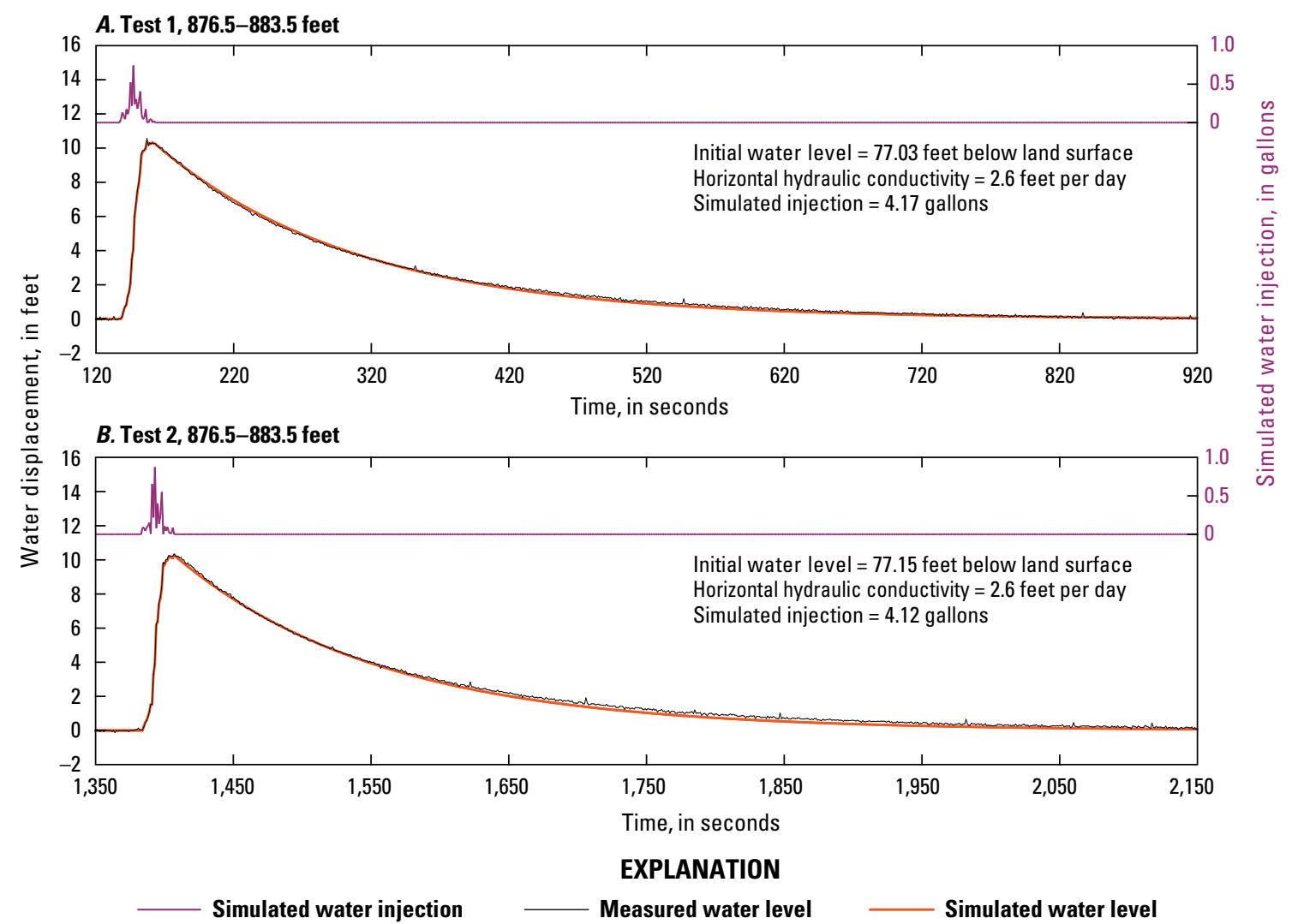

Figure 11. Measured and simulated water levels and simulated injection of water for packer-isolated interval 876.5- to 883.5-feet in borehole 33P028 at Fort Stewart, GA, December 6, 2009. Both tests were reported to be 10-gallon slug tests and both roughly yielded a hydraulic conductivity of 2 feet per day. (A) Test 1, (B) Test 2. 


\section{Aquifer Tests}

Aquifer tests were conducted at Fort Stewart to estimate the transmissivity of the Upper and Lower Floridan aquifers and to determine the effects of pumping one aquifer on water levels in the other aquifer. A 24-hour aquifer test was performed during March 3-4, 2010, in well 33P029 open to the Upper Floridan aquifer, and a 72-hour aquifer test was performed during March 8-11, 2010, in well 33P028 open to the Lower Floridan aquifer.

The Upper Floridan aquifer well 33P025, less than $2 \mathrm{mi}$ to the east, was used as an observation well for both aquifer tests (fig. 12). During the 24-hour aquifer test at well 33P029, wells $33 \mathrm{P} 028$ and $33 \mathrm{P} 025$ were observation wells; during the 72-hour aquifer test at well 33P028, wells 33P029 and 33P025 were observation wells. As a result, each aquifer test had one pumped well and two observation wells.

Wells 33P028 and 33P029 were monitored at least from February 24 to March 16, 2010. This period included a pre-test time of slightly more than 4.5 days, the 24 -hour aquifer test period, a recovery period of about 4 days, the 72-hour aquifer test period in the Lower Floridan aquifer, and a post-test period of approximately 4 days (fig. 13). Well 33P025 was monitored from February 25 to March 11, 2010. Details on these tests are provided in subsequent sections, and results are summarized in table 6 .

\section{Drawdown Estimation}

Drawdown for the three monitored wells was estimated by using a procedure developed by Halford (2006a) to filter water-level data for effects of barometric pressure, earth tide, and long-term trends. Time series related to known influences on water levels are used as explanatory variables to synthesize a water-level time series. The synthetic water levels are matched (fit) to measured water levels during periods that are unaffected by an aquifer test (hereinafter referred to as the fitting period) by adjusting the multiplier and phase shift of each explanatory time-series component. To improve the fit to measured water levels the resulting synthetic water levels also can be adjusted by a constant offset and slope with respect to time. Differences between the synthetic and measured water levels are minimized with a sum-of-squares objective function. With the synthetic water levels matching measured water levels during the fitting period, the synthetic water levels represent non-pumping water levels during the aquifer test. With the synthetic water level being the same as the measured water level, at the start of the aquifer test, the synthetic water level minus the measured water level during the aquifer test can be taken as the amount of occurring drawdown.

The filtering procedure was applied to water levels to determine drawdown curves in response to the 24-hour and 72-hour aquifer tests with emphasis on the observation wells. Filtering caused negligible modification to the drawdown of
Table 6. Summary of aquifer test results, Fort Stewart, GA, March 2010.

[UFA, Upper Floridan aquifer; LFCU, Lower Floridan confining unit; LFA, Lower Floridan aquifer; gal/min, gallon per minute; $\mathrm{ft}^{2} / \mathrm{d}$, square foot per day; PE, parameter estimation; - , not applicable]

\begin{tabular}{|c|c|c|c|}
\hline & \multirow{2}{*}{ Aquifer } & \multicolumn{2}{|c|}{ Aquifer test } \\
\hline & & 24-hour & 72-hour \\
\hline \multicolumn{4}{|c|}{ Test information } \\
\hline Location & & Well 33P029 & Well 33P028 \\
\hline Pumped aquifer & & UFA & LFA \\
\hline Test date, 2010 & & March 3-4 & March 8-11 \\
\hline Pumping rate (gal/min) & & 387 & 740 \\
\hline Analysis method & & Cooper-Jacob & $\begin{array}{l}\text { PE numerical } \\
\text { model }\end{array}$ \\
\hline \multicolumn{4}{|c|}{ Coefficients } \\
\hline Transmissivity $\left(\mathrm{ft}^{2} / \mathrm{d}\right)$ & UFA & $100,000^{*}$ & 90,000 \\
\hline Storativity (dimensionless) & & - & $7.50 \mathrm{E}-04$ \\
\hline Transmissivity $\left(\mathrm{ft}^{2} / \mathrm{d}\right)$ & LFCU & - & 4,000 \\
\hline Storativity (dimensionless) & & - & $6.80 \mathrm{E}-04$ \\
\hline Transmissivity $\left(\mathrm{ft}^{2} / \mathrm{d}\right)$ & LFA & - & 7,000 \\
\hline Storativity (dimensionless) & & - & $1.50 \mathrm{E}-03$ \\
\hline \multicolumn{4}{|c|}{ Maximum drawdown (feet) } \\
\hline Well 33P025 & UFA & $<0.1$ & 0.3 \\
\hline Well 33P029 & & 4.1 & 0.4 \\
\hline Well 33P028 & LFA & 0.2 & 38.8 \\
\hline
\end{tabular}

*Rounds a transmissivity of $120,000 \mathrm{ft}^{2} / \mathrm{d}$ to one significant figure.

the pumped well because the magnitude of the drawdown signal, more than $4 \mathrm{ft}$, obscured any signals corresponding to non-pumping influences, which probably ranged from a few hundredths of a foot to less than $0.4 \mathrm{ft}$ (fig. 14). Pre-test water levels indicated a prominent (up to $0.25 \mathrm{ft}$ ) cyclic diurnal fluctuation in water levels, however, characteristic of earth tides.

Barometric pressure and gravity along with water levels from two background wells (33M004 and 34N089) were used to filter out non-pump influences (fig. 14). Barometricpressure data were compiled from an on-site barometer and from hourly barometric-pressure data from National Oceanic and Atmospheric Administration (NOAA) weather station KLHW, located $3.35 \mathrm{mi}$ southeast of the aquifer-test site (KLHW location shown in fig. 1). The time series spreadsheet from Halford (2006a) generates gravity time series from entered values of latitude, longitude, and land-surface altitude. Gravity is used as a surrogate for earth tides and is expressed as microgravity deviation from average. Both background wells are open to the Upper Floridan aquifer. Pre-aquifer-test water levels in the background wells were similar to water levels in wells 33P025, 33P028, and 33P029 (fig. 14). 


\section{A. Aquifer test layout}

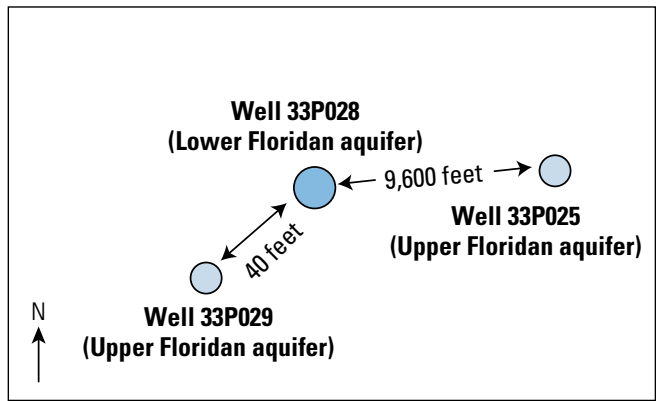

\section{EXPLANATION}

Well open interval

Figure 12. Location and open interval of wells used for the 72-hour aquifer test at Fort Stewart, GA. (A) Diagram showing aquifer-test layout, $(B)$ Schematic cross section showing the open intervals of the wells in relation to major hydrogeologic units (John S. Clarke, U.S. Geological Survey, written commun., January 2011).

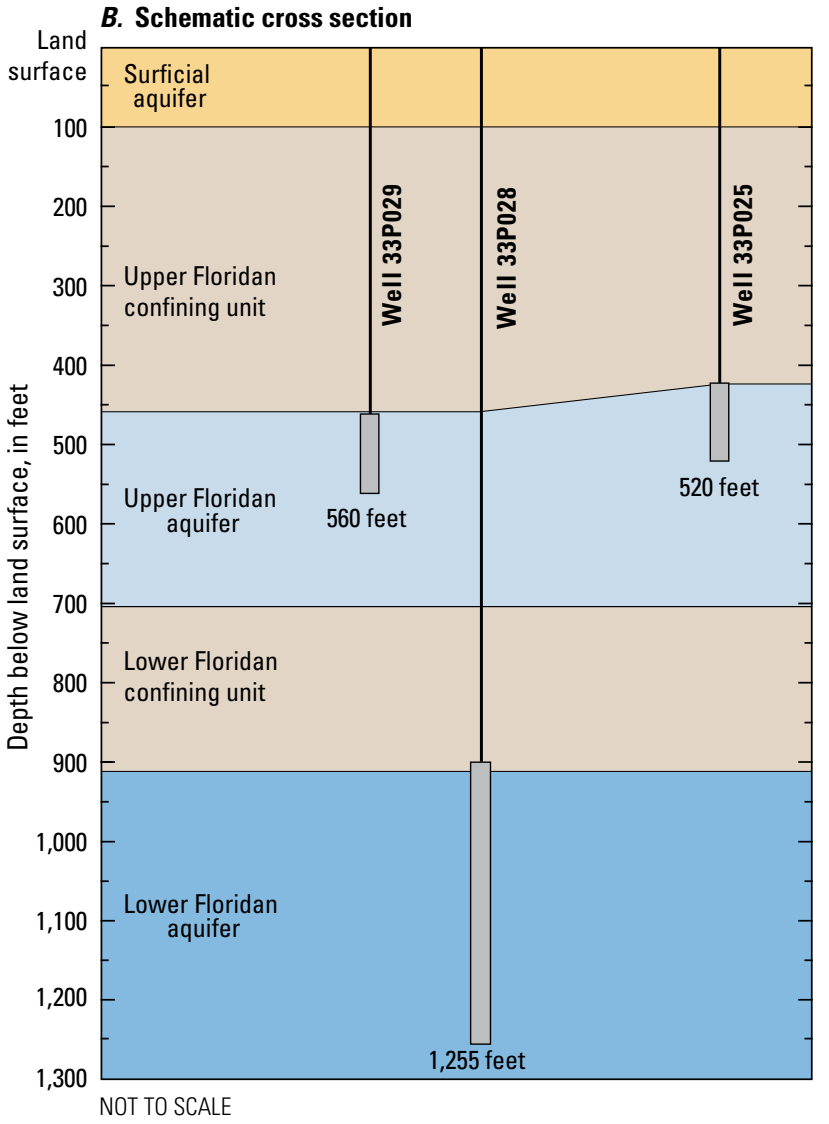

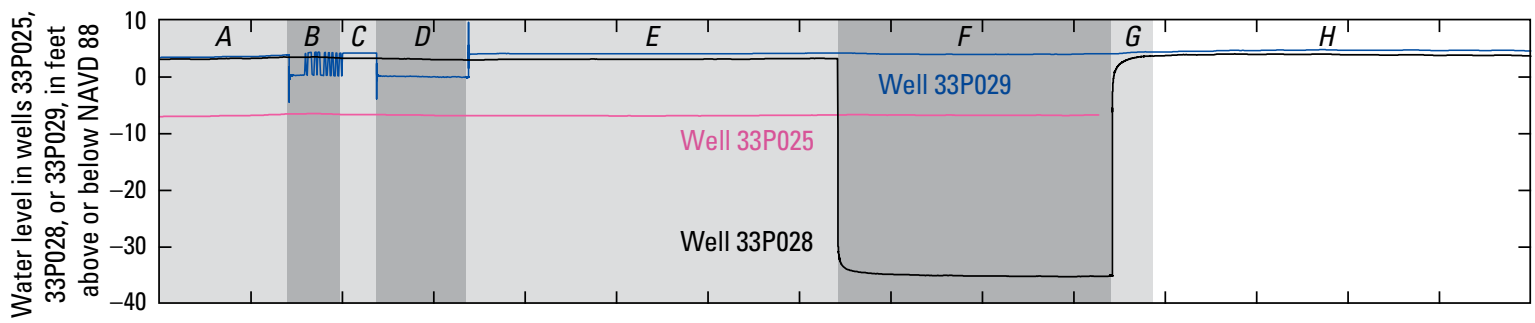

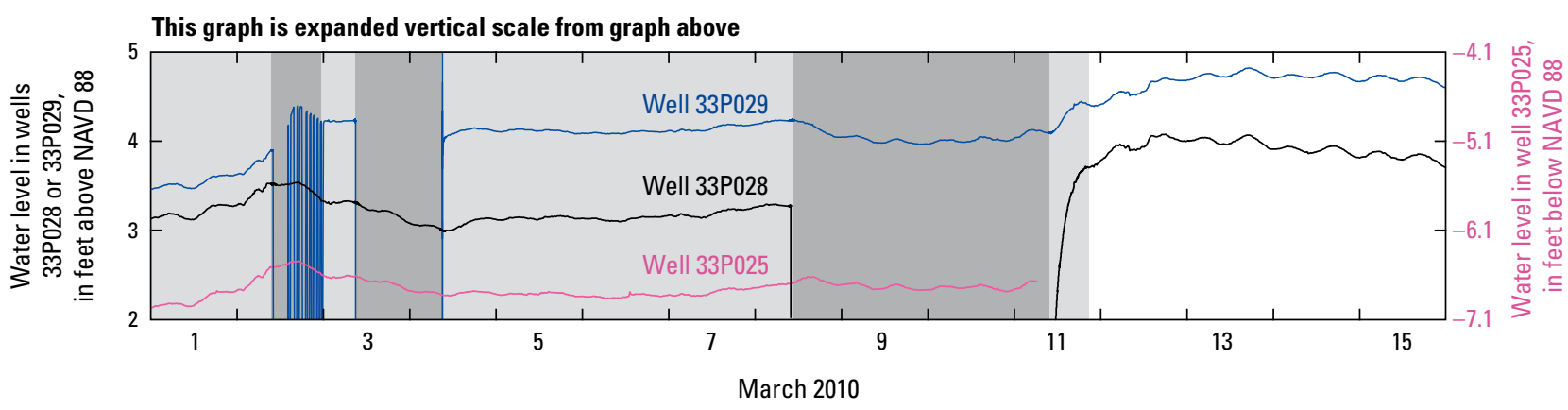

Figure 13. Raw, unfiltered water levels in wells 33P023, 33P029, and $33 \mathrm{PO} 025$ before, during, and after the 24-hour Upper Floridan and 72-hour Lower Floridan aquifer tests at Fort Stewart, GA, March 1-15, 2010. (A) Before aquifer-test pumping, (B) Failed aquifer test and well development (intermittent pumping), (C) Well recovery, $(D)$ Upper Floridan 24-hour aquifer test, (E) Well recovery, (F) Lower Floridan 72-hour aquifer test, $(G)$ Dominant recovery, $(H)$ Dominant non-pumping influences. 

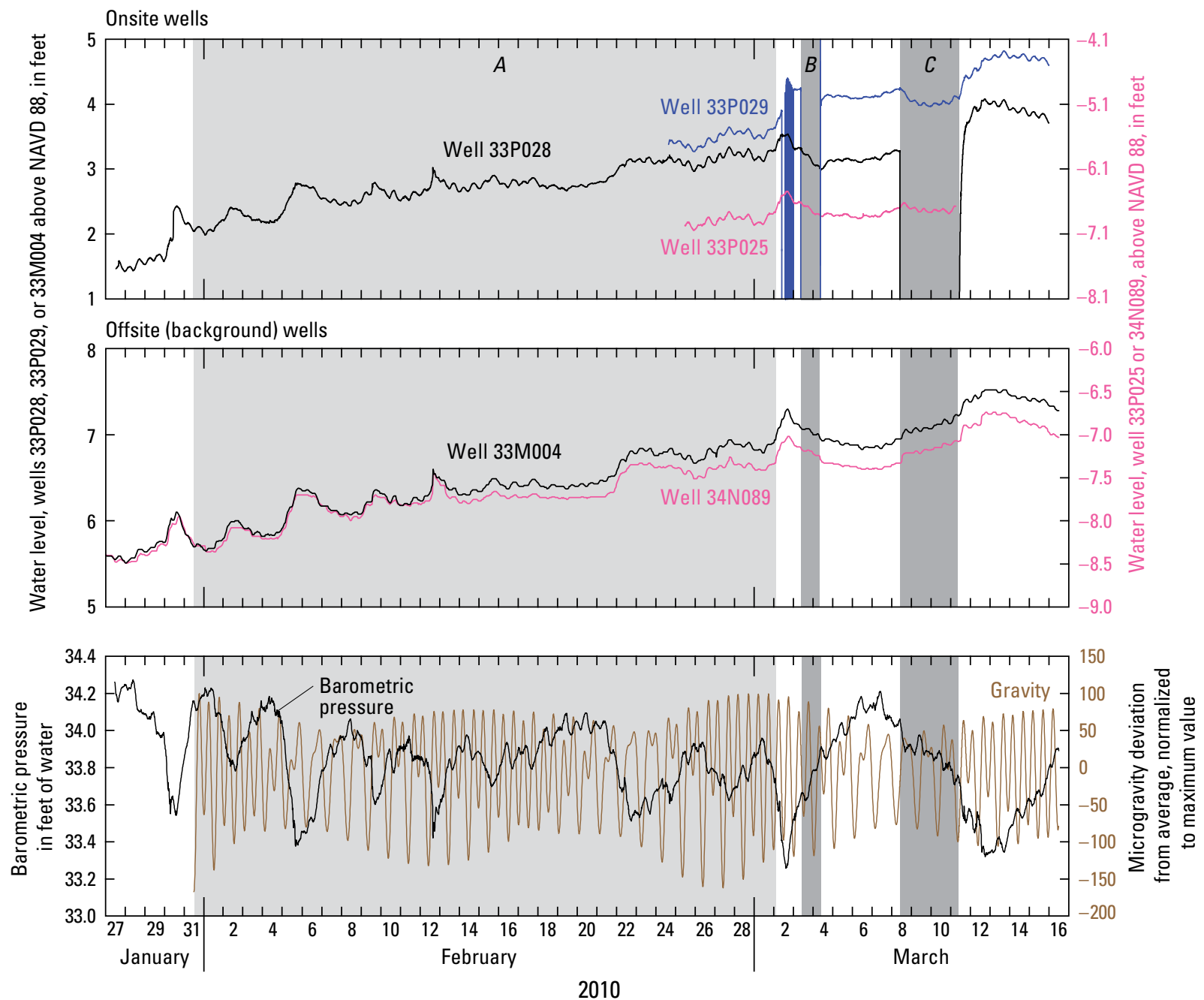

Figure 14. Water-level fluctuations in monitored wells and background wells and fluctuations in barometric pressure and gravity, used in the aquifer tests at Fort Stewart, GA, January 27March 16, 2010. (A) Fitting period for well 33P028, (B) Upper Floridan 24-hour aquifer test, (C) Lower Floridan 72-hour aquifer test. 
Water-level and barometric-pressure data for well 33P028 and background wells were available for the month prior to pumping associated with the aquifer tests (fig. 14). The pre-aquifer-test fitting period to match synthetic water levels with measured water levels in well 33P028 spanned from noon on January 31 to 3:00 a.m. on March 2. The goodness of fit was expressed with the root mean square error (RMSE) of the difference between the synthetic and measure water levels. Synthetic water levels match measured water levels for well 33P028 well with a RMSE of $0.0195 \mathrm{ft}$ (fig. 15). Multipliers and phase shifts of explanatory time-series components that matched synthetic water levels with measured water levels at well 33P028 during the fitting period were used to synthesize water levels for well 33P028 during the aquifer tests. There are 10 explanatory time-series components - each of the two background wells and barometric pressure have three components: the data, 6-hour moving average of the data, and a residual (data minus 6-hour moving average). The tenth explanatory time-series component was microgravity deviation from normal.

Water-level data for wells 33P029 and 33P025 were available for a limited period of about 4.5 days before the pumping associated with the aquifer tests (fig. 14). The period was too short to be a fitting period for these wells. The similarity of water levels in wells 33P025 and 33P029 to those in well 33P028 during this time allowed use of the same multipliers and phase shifts developed to match synthetic water levels with measured water levels for well 33P028 for use in matching synthetic water levels with measured water levels for wells 33P025 and 33P029. It was assumed that water levels in the two wells were similar to those in pumped well 33P028 during the 1-month pre-aquifer-test fitting period.

The offset and slope were independently adjusted for each of the three wells (33P028, 33P029, and 33P025) for each time period. As a result, each synthetic water-level time series has the same multipliers and phase shifts but different offsets and slopes. The synthetic water level for a well $w$ during a given time period $j$ at a given time $t$, is:

$$
\operatorname{Syn}_{(w, j, t)}=C_{(w, j)}+m_{(w, j)} \times\left(t-t_{0}\right)+\sum_{i=1}^{n} a_{i} \times V_{\left(i, t+\varphi_{i}\right)},
$$

where

$$
\begin{aligned}
& \operatorname{Syn}_{(w, j, t)} \quad \text { is the synthetic water level of well } w \text { during } \\
& \text { time period } j \text { at time } t \text {, in feet; } \\
& C_{(w, j)} \quad \text { is the offset for well } w \text { during time period } j, \\
& \text { in feet; } \\
& m_{(w, j)} \quad \text { is the linear water-level trend with respect } \\
& \text { to time (slope) for well } w \text { during time } \\
& \text { period } j \text {, in feet per day; } \\
& t_{0} \quad \text { is an arbitrary reference time; }\left(t-t_{0}\right) \text { is in days; } \\
& n \quad \text { is the number of explanatory time-series } \\
& \text { components, } 10 \text { in this study; } \\
& a_{i} \quad \text { is the amplitude of the multiplier for the } \\
& i^{\text {th }} \text { explanatory time-series component, } \\
& \text { in feet per unit of the explanatory } \\
& \text { time-series component; } \\
& V_{(i, t+\varphi)} \quad \text { is the value of the } i^{\text {th }} \text { explanatory time-series } \\
& \text { component at time } t+\varphi \text {; and } \\
& \varphi_{i} \quad \text { is the phase shift for the } i^{\text {th }} \text { explanatory } \\
& \text { time-series component, in days. }
\end{aligned}
$$

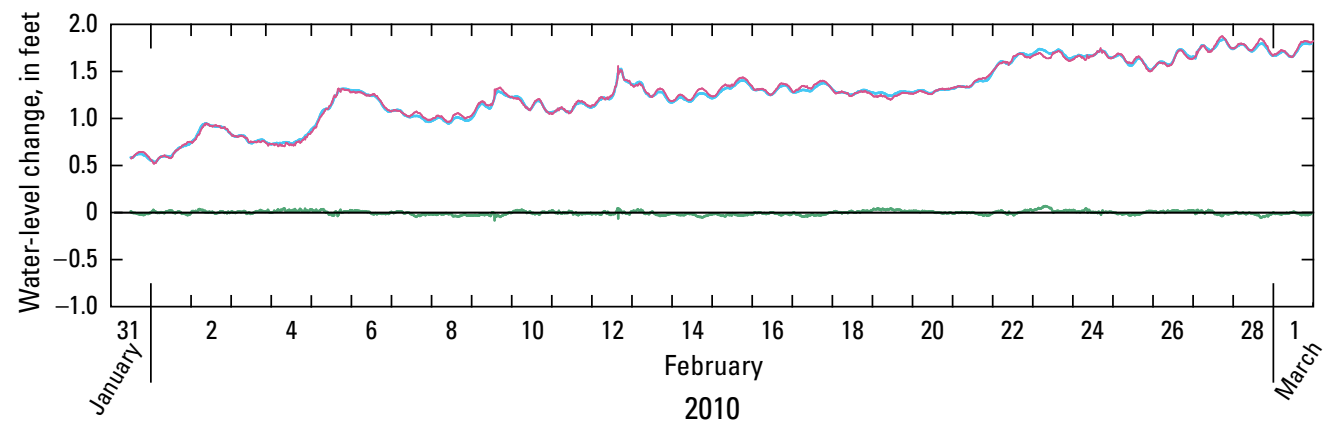

EXPLANATION

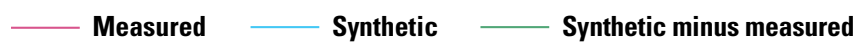

Figure 15. Measured and synthetic water levels for well 33P028 during fitting period, January 31-March 1, 2010, at Fort Stewart, GA. Root mean square error of the difference between synthetic and measured water levels is 0.0195 foot. 
Values of $a_{i}$ and $\varphi_{i}$ are used to best fit synthetic water levels to measured water levels for well 33P028 during the 1-month fitting period (fig. 15). Each time period $(j)$ is either a fitting period or an aquifer-test period. Adjustments to the offset and slope were made to either evaluate the fit of synthetic water levels to measured water levels during a fitting period or to set the synthetic water level to be that of the measured water level just prior to the start of the aquifer tests. Thus, the synthetic water level minus the measured water level then represented drawdown induced by pumping at well 33P029 during the 24-hour aquifer test or at well 33P028 during the 72-hour aquifer test.
Adjusting the offset and slope allowed synthetic water levels, originally from well 33P028, to fit measured water levels in wells 33P029 and 33P025. As a quality-assurance check, synthetic water levels were adjusted to best fit measured water levels during the 4.5-day fitting period for each observation well. Synthetic water levels from 33P028 also were fit to measured water levels of a short fitting period, similar to the short fitting period of wells 33P025 and 33P029 for comparison. RMSE values of the difference between synthetic and measured water levels were small, less than or equal to $0.022 \mathrm{ft}$ for the three wells (fig. 16).
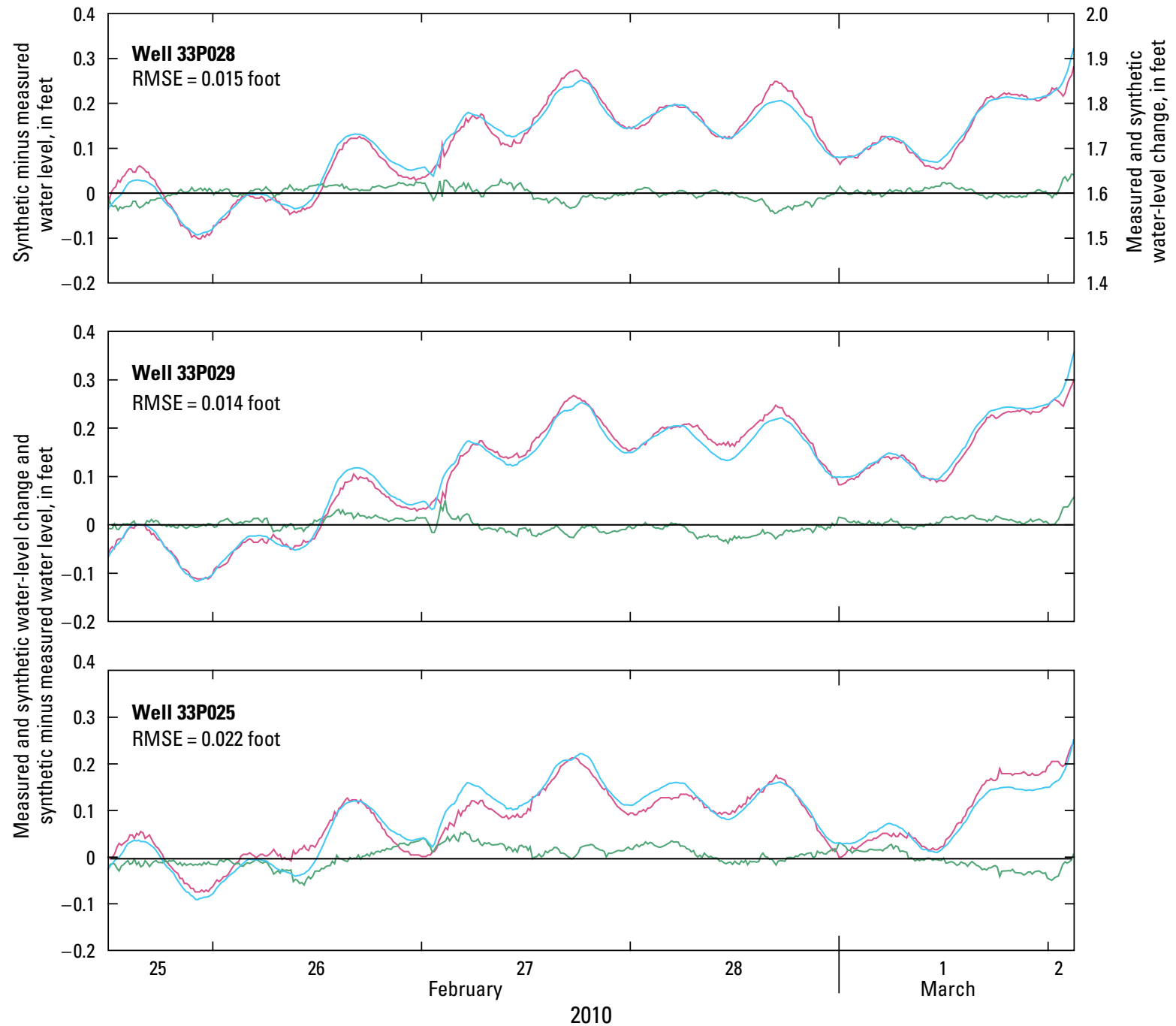

EXPLANATION

Measured _ Synthetic _ Synthetic minus measured

Figure 16. Fit of synthetic water levels to measured water levels for wells 33P028, 33P029, and 33P025, Fort Stewart, GA, February 25-March 2, 2010. Root mean square error (RMSE) shown is for the difference between synthetic and measured water levels. 


\section{4-Hour Aquifer Test}

The 24-hour aquifer test at well 33P029 was first attempted on March 2, 2010, at 10:00 a.m. Heavy drilling mud in the water pumped from the well affected water levels and pumping rates. After about 3 hours 45 minutes, the aquifer test was aborted and the well was developed by intermittently pumping until midnight (about 10 hours). Well 33P029 was then allowed 9 hours of recovery before the aquifer test was re-started at 9:00 a.m. on March 3, 2010. Time constraints did not allow further well recovery.

Aquifer-test pumping at Upper Floridan aquifer well 33P029 began on March 3, 2010, at 9:00 a.m. and continued for 24 hours 5 minutes to March 4, 2010, at 9:05 a.m. The well was pumped at a rate of $387 \mathrm{gal} / \mathrm{min}$. In response to the start of pumping, the water level in well 33P029 dropped almost instantly with some oscillation. The oscillation damped to zero within 90 seconds, and water levels seemed to stabilize in the short term (fig. 17). From about 90 seconds to about 2.5 hours, drawdown consistently increased with log time (constant log cycle). From 2.5 to 24 hours, drawdown increased at a lower rate than had occurred during the first 2.5 hours (fig. 18). At the end of the 24-hour pumping period, the water level rose almost instantly with some oscillation that damped to zero within 100 seconds. The oscillating period was about 20 seconds (fig. 17).

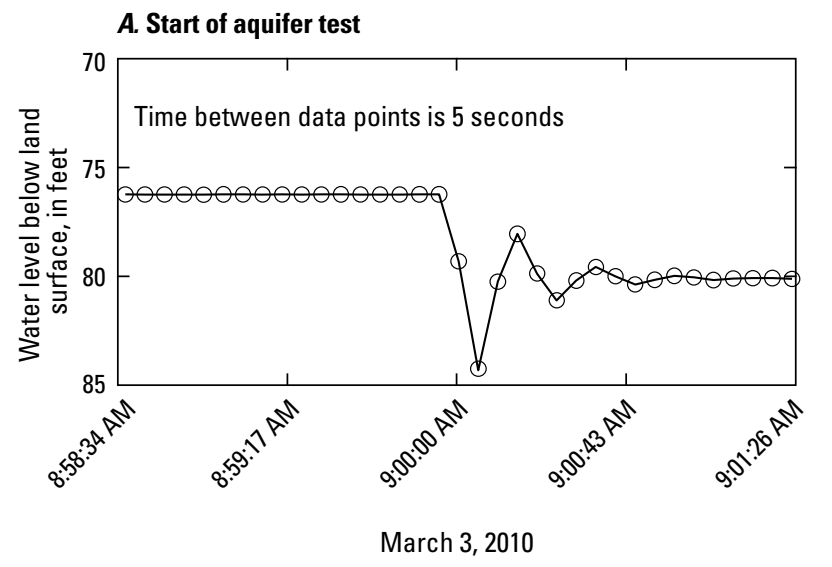

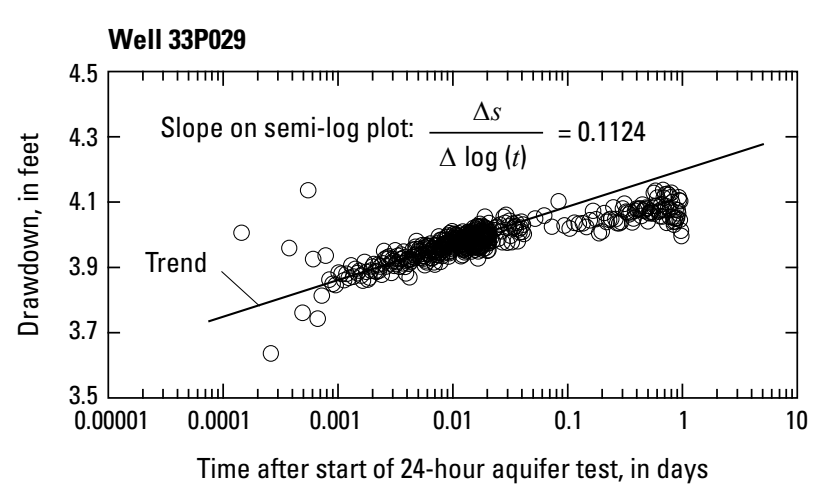

Figure 18. Semi-log graph of drawdown during the 24-hour aquifer test in well 33P029 at a pumping rate of 387 gallons per minute at Fort Stewart, GA, March 3-4, 2010.

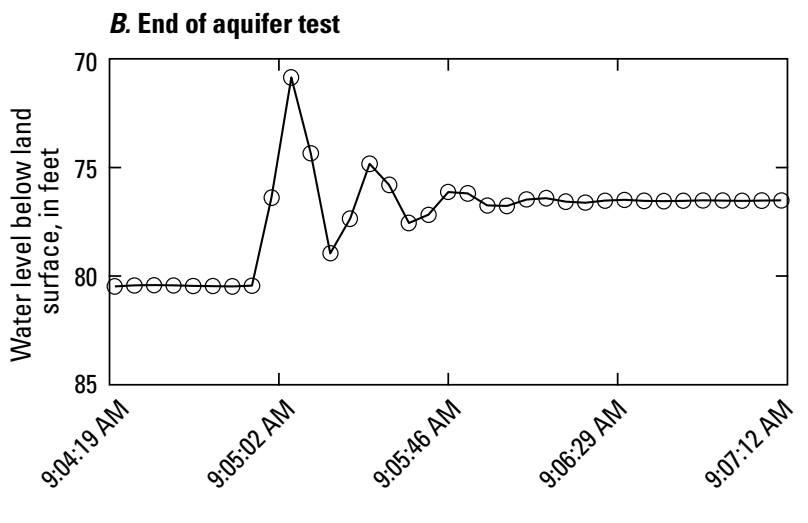

March 4, 2010

Figure 17. Water levels at the $(A)$ start and $(B)$ end of the 24-hour aquifer test in well $33 \mathrm{P} 029$ at Fort Stewart, GA, March 3-4, 2010. 


\section{Drawdown Response}

Total decline in water level (drawdown plus nonpumping influences) during the 24-hour aquifer test at well 33P029 equaled about $4.26 \mathrm{ft}$, from 76.24 to $80.50 \mathrm{ft}$ below land surface. Adjusting for a minor linear trend indicates a corrected drawdown of $4.1 \mathrm{ft}$ (fig. 19).

Total water-level declines in observation wells 33P028 and 33P025 were obscured by barometric-pressure changes and earth tides and complicated by pumping during the failed aquifer test and well development in well 33P029 (fig 19). Water levels in well 33P025 could not be adequately filtered to remove fluctuations in the value of synthetic water level minus measured water level. Values of synthetic water level minus measured water level for well 33P025 actually increased hours before the start of the failed aquifer test on March 2, then increased again soon after the start of the 24-hour aquifer test on March 3. Based on the amplitude in the fluctuations in synthetic water level minus measured water level, whatever actual response that might have occurred in well 33P025 to pumping at well 33P029 would be less than $0.1 \mathrm{ft}$. Water levels in well 33P028 were adequately filtered, revealing drawdown during the failed aquifer test and subsequent well development on March 2, and the 24-hour aquifer test on March 3-4. The value of synthetic water level minus measured water level, set at zero at the beginning of the failed aquifer test, was about $0.12 \mathrm{ft}$ during the failed aquifer test and subsequent well development on March 2. Drawdown started to decrease about 5 hours 30 minutes after the cessation of well development; however, it is unsure whether this was actual recovery or a temporary fluctuation. During the 24-hour aquifer test, the value of synthetic water level minus measured water level increased from 0.12 to $0.24 \mathrm{ft}$. Even though recovery during the 9-hour break between the two pumping periods is uncertain, it is assumed that at least some recovery from pumping on March 2 occurred during the 24-hour aquifer test, as indicated by the sag in the lower dashed line in fig. $19 B$. Such recovery would mean that drawdown in response to the 24-hour aquifer test was greater than $0.12 \mathrm{ft}$ and probably close to $0.2 \mathrm{ft}$.

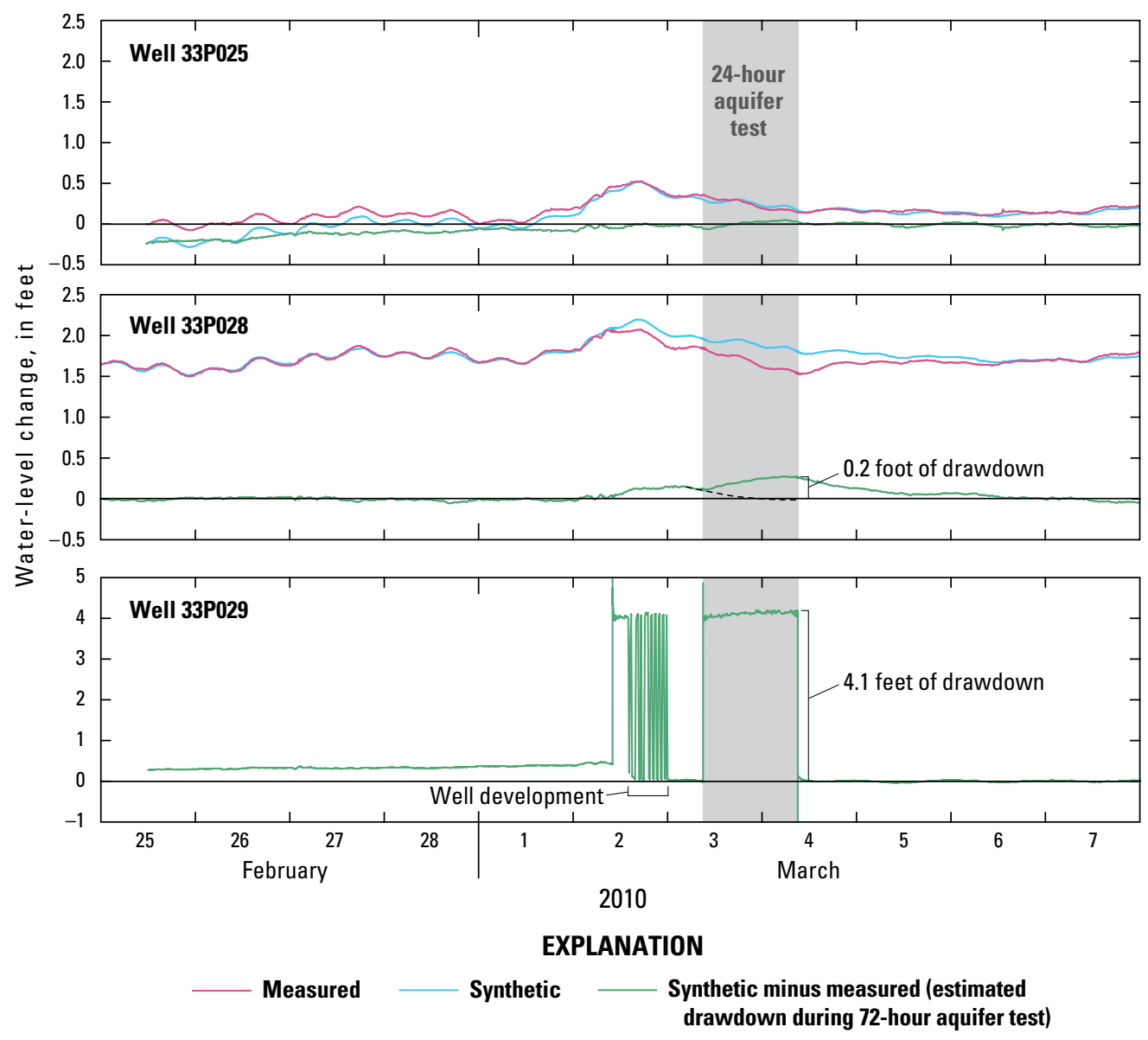

Figure 19. Measured and synthetic water levels and estimated drawdown in wells $33 \mathrm{P025}$ and $33 \mathrm{P} 028$ during the 24-hour aquifer test conducted in the Upper Floridan aquifer well 33P029 at Fort Stewart, GA, February 25-March 7, 2010. 


\section{Aquifer Test Analysis}

The Cooper-Jacob, straight-line method (Cooper and Jacob, 1946) was applied to the drawdown data from pumped well 33P029 to determine the transmissivity of the Upper Floridan aquifer (fig. 18). The uncertainty associated with various factors indicates that the transmissivity probably is between 100,000 and 140,000 square feet per day $\left(\mathrm{ft}^{2} / \mathrm{d}\right)$. The best fit of the log cycle of drawdown to the drawdown data between 90 seconds and 2.5 hours is a slope of about 0.1124 , yielding a transmissivity value of about $120,000 \mathrm{ft}^{2} / \mathrm{d}$. The $\log$ cycle still fits these data well with slopes ranging from 0.1247 to 0.1033 , yielding transmissivity values from 110,000 to $130,000 \mathrm{ft}^{2} / \mathrm{d}$. Therefore, uncertainty as a result of curve fit is about $\pm 10,000 \mathrm{f}^{2} / \mathrm{d}$. Drawdown data between 2.5 hours and 1 day seem to be affected by a recharge boundary or some large-scale aspect of the Upper Floridan aquifer and were not used to determine transmissivity. The results are within the range of values reported by Clarke and others (2004) for the Upper Floridan aquifer, although they are near the lower end of that range. Clarke and others (2004) report transmissivity values for the Upper Floridan aquifer in Liberty County from $124,000 \mathrm{ft}^{2} / \mathrm{d}$ to $160,000 \mathrm{ft}^{2} / \mathrm{d}$. The value of $124,000 \mathrm{ft}^{2} / \mathrm{d}$ was from earlier work done at Fort Stewart (Warren, 1944).

Some recovery from the failed aquifer test and well development might have caused a slight overestimation in the transmissivity of the Upper Floridan aquifer; however, the offset used to synthesize water levels might have neutralized this overestimation. As indicated in figure 17, most of the drawdown in response to pumping or recovery in response to cessation of pumping occurred almost immediately. The subsequent drawdown, while minor, was crucial in determining transmissivity. This minor drawdown took hours to occur. As this minor, but crucial, drawdown in response to pumping the Upper Floridan aquifer occurred over many hours, the recovery from such pumping so, too, may have occurred over many hours. Simulations of water levels using the simple Theis model indicate that some recovery from the failed aquifer test and well development might have caused an overestimation of transmissivity by about $10,000 \mathrm{ft}^{2} / \mathrm{d}$. However, the slope correction of $0.03 \mathrm{ft} / \mathrm{d}$ that was added to the synthesized water levels neutralizes this overestimation. The final estimation of transmissivity for the Upper Floridan aquifer from the 24-hour aquifer test, rounded to one significant digit, is $100,000 \mathrm{ft}^{2} / \mathrm{d}$.

\section{2-Hour Aquifer Test}

Pumping at Lower Floridan aquifer well 33P028 began on March 8, 2010, at 10:00 a.m. and continued for 72 hours 5 minutes to March 11 at 10:05 a.m. The well was pumped at a rate of $740 \mathrm{gal} / \mathrm{min}$. The pump lacked a check valve; therefore, when aquifer-test pumping ceased, a slug of water siphoned back into the well. As a result, the water level has a slug signature during the first minute of recovery (fig. 20).

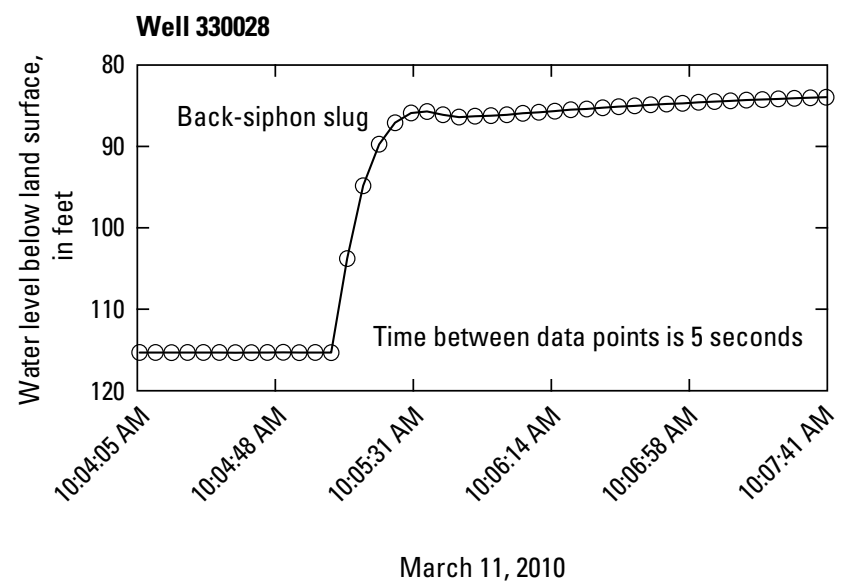

Figure 20. Effects on water level in well 33P028 at the end of the 72-hour aquifer test when a slug of water siphoned back into the well immediately after pumping stopped at Fort Stewart, GA,

March 11, 2010.

Within minutes, the effect of the slug was no longer apparent in recovery. Within about 30 hours, the water level in pumped well 33P028 recovered to where non-pump influences dominated the hydrograph.

\section{Drawdown Response}

Total decline in water level (drawdown plus external influences) during the 72-hour aquifer test at pumped well 33P028 equaled about $38.4 \mathrm{ft}$, from 78.5 to $116.9 \mathrm{ft}$ below land surface. Adjusting for a minor linear trend indicates a corrected drawdown of $38.8 \mathrm{ft}$ (fig. 21). Drawdown at the pumped well as a function of log (time) was nonlinear as indicated by the continuously decreasing log cycle of drawdown with time (fig. 22). The nonlinear nature of drawdown on the semi-log plot precluded the viable use of an analytical method for estimating the transmissivity of the Lower Floridan aquifer.

Total drawdown rates at the end of the 72-hour aquifer test in observation wells 33P025 and 33P029 in Upper Floridan aquifer were 0.3 and $0.4 \mathrm{ft}$, respectively (fig. 21). Some fluctuations in the value of synthetic water level minus measured water level remained after filtering, but water levels from both observation wells adequately filtered influences of barometric pressure and earth tides. The main fluctuation in the value of synthetic water level minus measured water level that seemed to escape filtering for both observation wells had a wavelength of 1 day, reaching a maximum and minimum in the early afternoon and early morning, respectively, with an amplitude up to about $0.05 \mathrm{ft}$. Offsets and slopes were set for the observation wells so that the synthetic water level was the same as the measured water level at the start of the 72-hour 
aquifer test. For well 33P029, the offset and slope were set with the assumption that minor recovery was still occurring 1 day after the 24-hour aquifer test in the Upper Floridan aquifer but was negligible by the start of the 72-hour aquifer test. As a result, values of the synthetic water level minus the measured water level for well 33P029 are set by the offset and slope to recede from about $0.1 \mathrm{ft}$ on March 5, 2010, to zero on March 8, 2010.

No record of recovery is available for well 33P025 because of equipment malfunction. Most drawdown in well 33P029 recovered within about 3 days following the end of the 72-hour aquifer test.

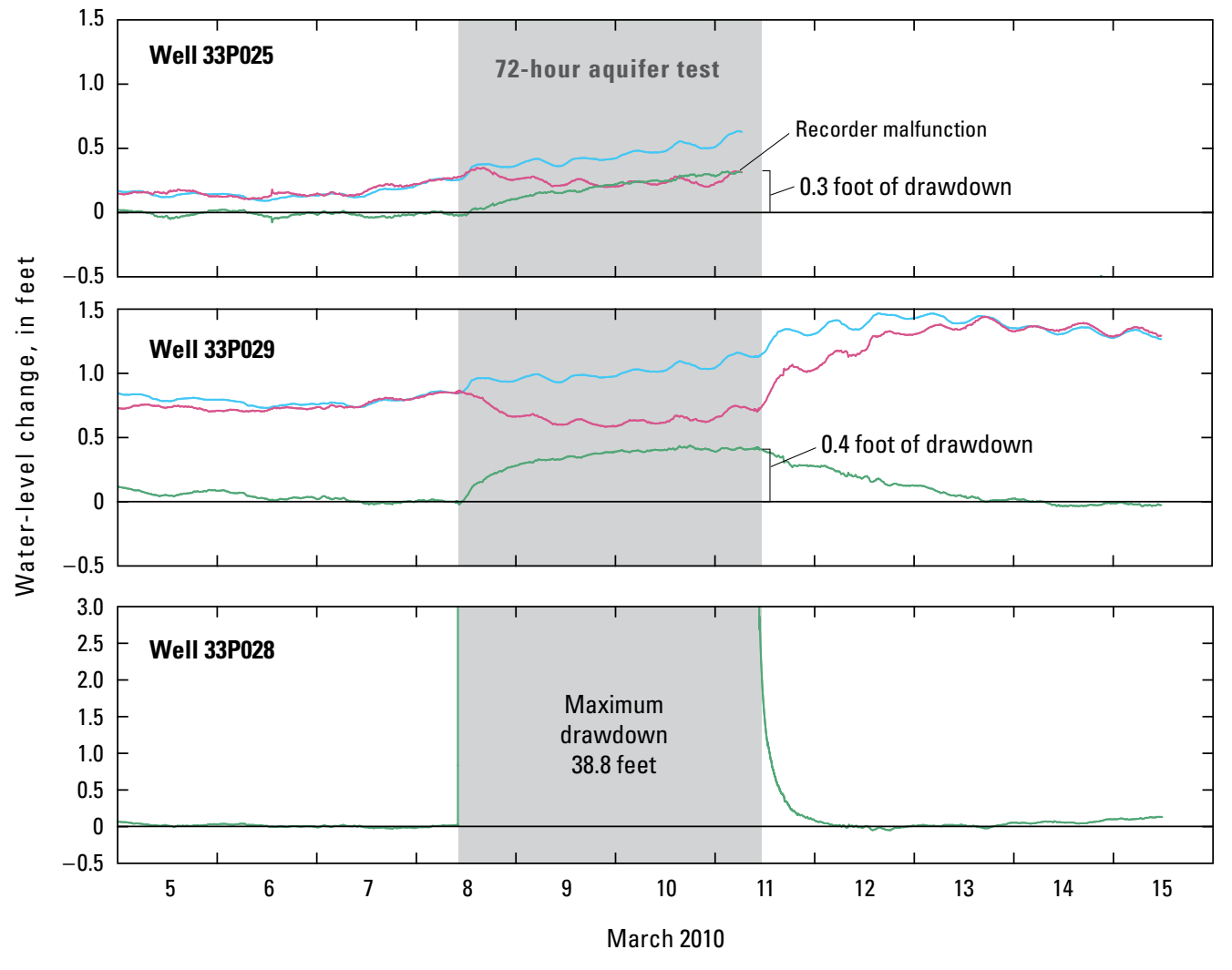

EXPLANATION

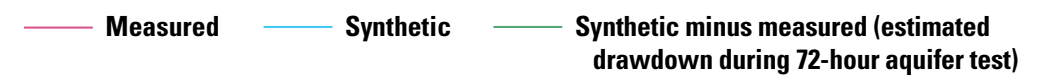

Figure 21. Measured and synthetic water levels and estimated drawdown in wells $33 \mathrm{P} 025$ and 33P029 during the 72-hour aquifer test conducted in Lower Floridan aquifer well $33 \mathrm{P028}$ at Fort Stewart, GA, March 5-15, 2010.

Figure 22. Semi-log plot of drawdown in pumped well $33 \mathrm{P} 028$ during the 72-hour aquifer test at Fort Stewart, GA, March 8-11, 2010.

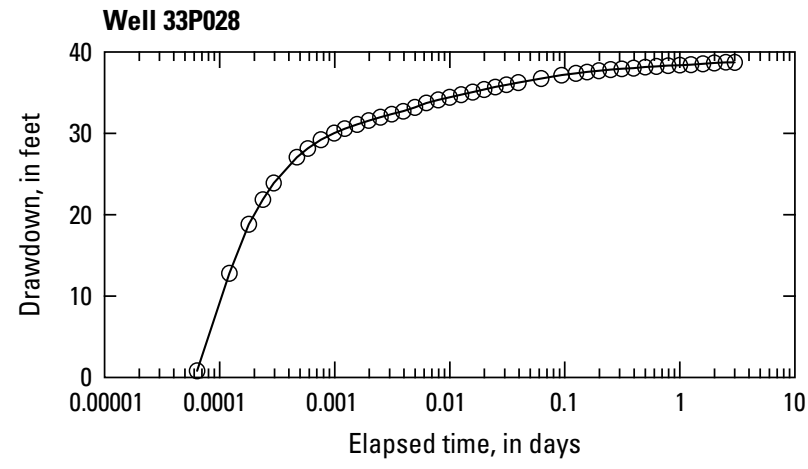




\section{Model Simulation of the Lower Floridan Aquifer Test}

Because of the nonlinear nature of the semi-log plot, transmissivity of the Upper and Lower Floridan aquifers was estimated by using the numerical model MODFLOW-96 (McDonald and Harbaugh, 1988; Harbaugh and McDonald, 1996) with the calibration tool MODOPTIM (Halford, 2006b). Hydraulic properties were estimated by minimizing the weighted sum-of-squares of differences between simulated and measured drawdown. Estimated drawdown, discussed in previous sections, will be referred to here as "measured drawdown." Drawdown values in observation wells were weighted slightly more than drawdown in the pumped well during calibration to compensate for the larger measured drawdown in the pumped well relative to that in the observation wells. In addition to weighting favorably to the drawdown of observation wells, a constant amount of drawdown was subtracted from drawdown in the pumped well. This equalization of drawdown magnitude prevents the observation-well drawdown values from being superfluous during the calibration process (Halford 2006b).

The aquifer system was simulated with a two-dimensional, axisymmetric, radial, transient groundwater-flow model that incorporated pumped well $33 \mathrm{P} 028$ and observation wells 33P029 and 33P025 (fig. 23). Horizontal hydraulic conductivity was assumed to be isotropic and homogeneous within each hydrogeologic unit. Specific storage was assumed to be homogeneous through the entire aquifer system. A vertical anisotropy ratio (vertical hydraulic conductivity divided by the horizontal hydraulic conductivity) of 0.1 was assumed for each hydrogeologic unit (table 7).

Five hydrogeologic units are represented in the modelthe surficial aquifer, Upper Floridan confining unit, Upper Floridan aquifer, Lower Floridan confining unit, and Lower Floridan aquifer (fig. 23). The model domain is discretized into 114 rows representing aquifer thickness and 59 columns representing the radial distance from center of pumped well $33 \mathrm{P} 028$ to the external model boundary. The model radially extends 200,000 ft from well 33P028 and represents the subsurface depth interval between $77 \mathrm{ft}$ (the estimated watertable depth) and 1,400 ft. Radial grid spacing (column width) increases from $0.51 \mathrm{ft}$ at pumped well 33P028 to $36,640 \mathrm{ft}$ at the edge of the model. Each row height represents a vertical thickness of $11.6 \mathrm{ft}$ of the simulated aquifers and intervening confining layers. The thin, unconfined, surfical aquifer was represented as a single layer and row in the model.

The radial distal edges to the well and the base of the model are simulated as no-flow boundaries; the upper boundary represents the water table. The aquifer-test stress period is represented by 53 time steps totaling slightly more than 3 days. Time steps ranged from about 0.47 seconds to 14 hours 25 minutes, with each succeeding time step increasing from the previous time step by a multiplier of 1.25 .
MODOPTIM (Halford, 2006b) was used to estimate horizontal hydraulic conductivity in the Upper Floridan aquifer, Lower Floridan confining unit, and Lower Floridan aquifer and to estimate a single value for the composite specific storage of all five hydrogeologic units represented in the model (fig. 23; table 7). Hydraulic properties of the surficial aquifer and Upper Floridan confining unit were not sensitive to parameter estimation; the horizontal hydraulic conductivity of these units was unchanged from the initial value of $0.01 \mathrm{ft} / \mathrm{d}$ used for calibration. The goodness of fit of simulated drawdown or recovery to measured drawdown indicates a successful calibration for wells 33P028 and 33P029 (fig. 24). Simulated values for drawdown for well 33P025 were about half the measured values for drawdown, which may be due to poor drawdown estimation or actual heterogeneity within the Upper Floridan aquifer that was not accounted for within the model.

Simulated transmissivity of the Lower Floridan aquifer was about 7,000 $\mathrm{ft}^{2} / \mathrm{d}$ (table 7), almost twice the transmissivity values simulated by a regional model of coastal Georgia (Payne and others, 2005) but within the range of values reported by Clarke and others (2004). Regional estimates of transmissivity derived from models usually are less than local estimates because of larger variability of aquifer properties compared with limited variability at local, aquifer-test scales (Lynn Torak, U.S. Geological Survey, written commun., 2010). Simulated transmissivity of the Upper Floridan aquifer was nearly $90,000 \mathrm{f}^{2} / \mathrm{d}$, slightly less than the transmissivity that was determined by using the straight-line method (Cooper and Jacob, 1946) on drawdown data from a 24-hour aquifer test at well 33P029. Using the vertical anisotropy $(0.1)$ and the horizontal hydraulic conductivity for the Lower Floridan confining unit $(17 \mathrm{ft} / \mathrm{d})$ from the model, vertical hydraulic conductivity for the Lower Floridan confining unit was estimated to be $1.7 \mathrm{ft} / \mathrm{d}$. This vertical hydraulic conductivity estimate is about four times the median of values directly determined from cores.

Parameter estimation and model simulation, in addition to collected data, indicate that the Lower Floridan confining unit at the study site has hydraulic properties similar to those of the Lower Floridan aquifer. The MODOPTIM estimated value of horizontal hydraulic conductivity of the Lower Floridan confining unit is essentially the same as that of the Lower Floridan aquifer. Further, the model parameter-estimation results indicate a high measure of redundancy in the horizontal hydraulic conductivity of the Lower Floridan confining unit and the Lower Floridan aquifer. The high measure of redundancy for these two parameters indicates that MODOPTIM would provide a better estimate of the horizontal hydraulic conductivity for both the Lower Floridan confining unit and the Lower Floridan aquifer as a single unit. The results of flowmeter surveys and slug tests support the hydrologic similarity between the two units at the study site. 


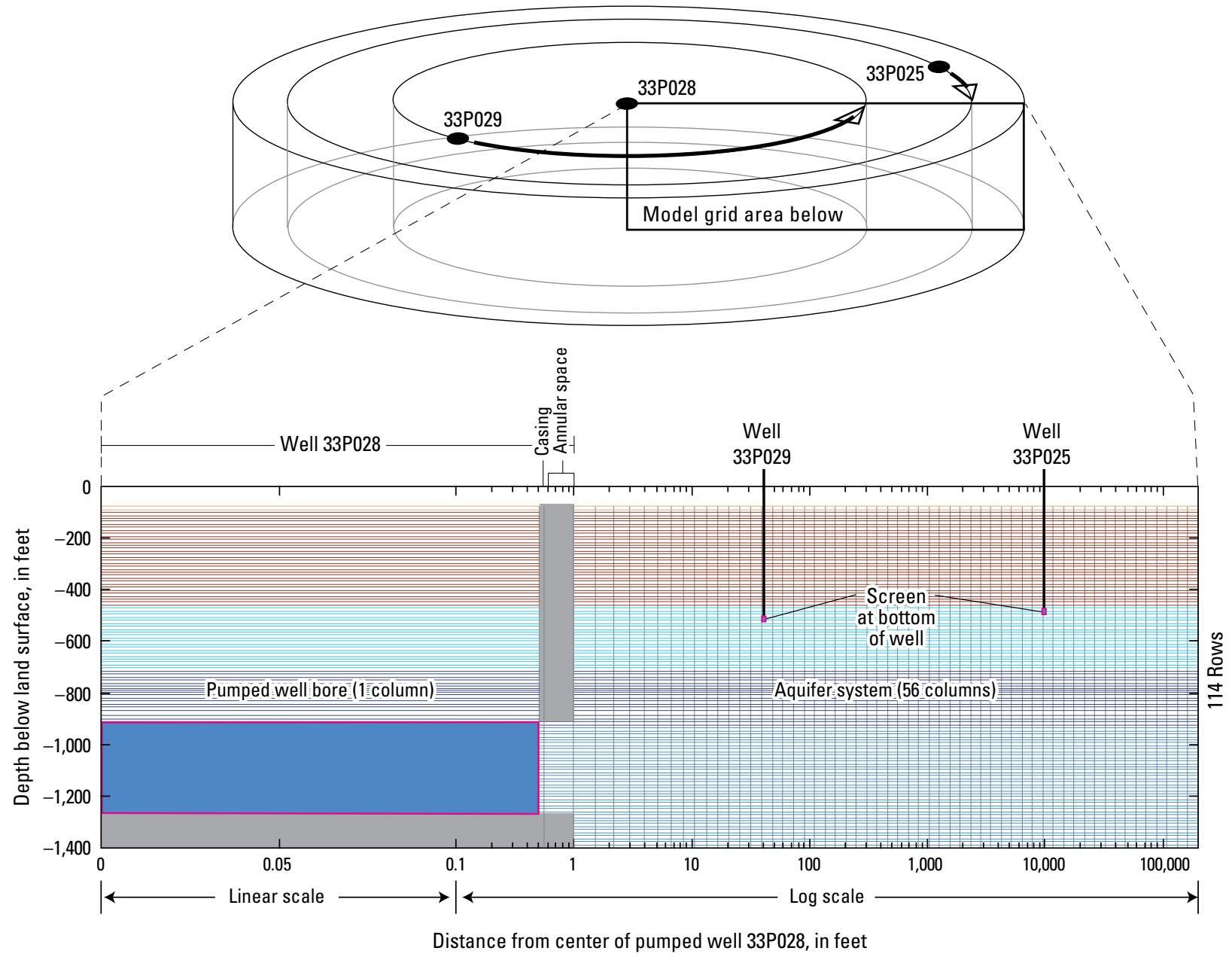

\section{EXPLANATION}

Row boundaries

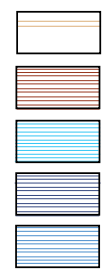

Surficial aquifer (1 row)

Upper Floridan confining unit (32 rows)

Upper Floridan aquifer (21 rows)

Lower Floridan confining unit (19 rows)

Lower Floridan aquifer (41 rows)

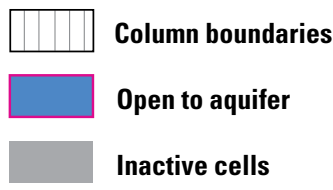

Figure 23. Axisymmetric radial model for 72-hour aquifer test at pumped well 33P028 at Fort Stewart, GA, March 8-11, 2010. 
Table 7. Hydraulic parameters that were used or estimated to fit simulated water levels to measured drawdown and recovery and estimated values of transmissivity and storativity for the 72-hour aquifer test at pumped well 33P028 and observation wells 33P029 and 33P025, Fort Stewart, GA, March 8-11, 2010.

[Kx, horizontal hydraulic conductivity; Kz, vertical hydraulic conductivity; Kz/Kx, vertical anisotropy; Ss, specific storage; ft/d, foot per day; $\mathrm{ft}^{2} / \mathrm{d}$, foot squared per day; bracketed numbers were estimated with a parameter-estimation program MODOPTIM (Halford, 2006b); NA, not applicable; *, the surficial aquifer was represented as one layer]

\begin{tabular}{|c|c|c|c|c|c|}
\hline \multirow[b]{2}{*}{ Hydrogeologic unit } & \multicolumn{5}{|c|}{ Hydraulic parameter } \\
\hline & $\underset{(\mathbf{f t} / \mathbf{d})}{\mathbf{K x}}$ & $\begin{array}{c}\mathrm{Kz} / \mathrm{Kx} \\
\text { (dimensionless) }\end{array}$ & $\begin{array}{c}\text { Ss } \\
\text { (1/feet) }\end{array}$ & $\begin{array}{l}\text { Thickness } \\
\text { (feet) }\end{array}$ & $\begin{array}{c}\text { Transmissivity } \\
\left(\mathrm{ft}^{2} / \mathrm{d}\right)\end{array}$ \\
\hline Surficial aquifer & 0.01 & 0.1 & [3.07E-06] & $11.6^{*}$ & NA \\
\hline $\begin{array}{l}\text { Upper Floridan } \\
\text { confining unit }\end{array}$ & 0.01 & 0.1 & {$[3.07 \mathrm{E}-06]$} & 371 & NA \\
\hline Upper Floridan aquifer & {$[355.785]$} & 0.1 & [3.07E-06] & 244 & 86,812 \\
\hline $\begin{array}{l}\text { Lower Floridan } \\
\text { confining unit }\end{array}$ & {$[17.0321]$} & 0.1 & {$[3.07 \mathrm{E}-06]$} & 220 & 3,747 \\
\hline Lower Floridan aquifer & [14.2962] & 0.1 & [3.07E-06] & 476 & 6,802 \\
\hline
\end{tabular}
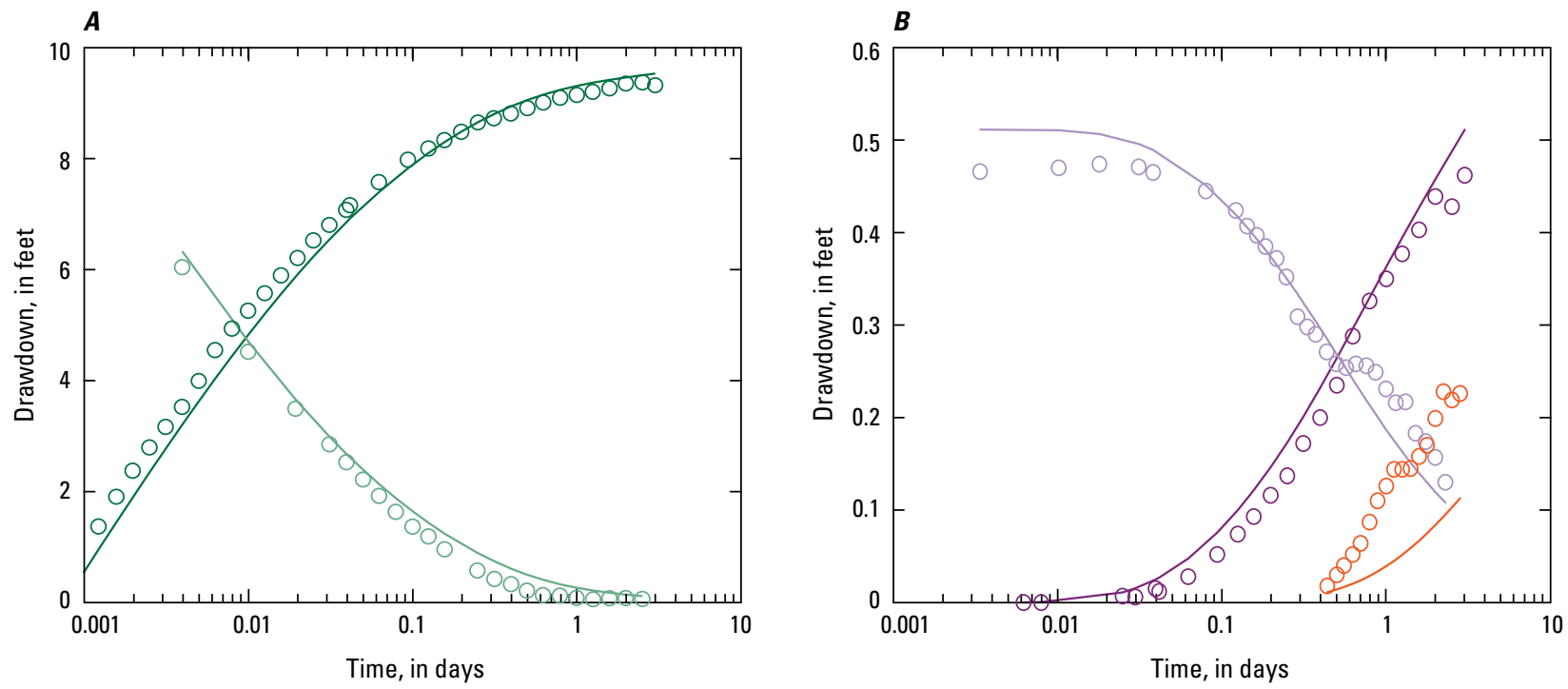

EXPLANATION

\begin{tabular}{cl} 
& Well 33P028 drawdown \\
\hline & Simulated \\
Measured \\
Well 33P028 recovery \\
Simulated \\
Measured
\end{tabular}

Well 33P029 drawdown
Simulated
Measured
Well 33P029 recovery
Simulated
Measured

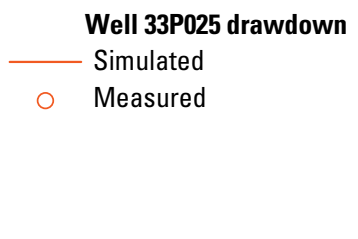

Figure 24. Simulated and measured water-level drawdown and recovery at ( $A$ ) pumped well $33 \mathrm{P028}$ and $(B)$ observation wells 33P029 and 33P025 (simulated and measured water-level drawdown only, at well 33P025) for the 72-hour aquifer test at Fort Stewart, GA, March 8-11, 2010. 


\section{Summary}

Site-specific hydrologic testing was conducted at Fort Stewart in Liberty County, GA, in late 2009 and early 2010 to determine the hydraulic characteristics of the Upper Floridan aquifer, Lower Floridan confining unit, and Lower Floridan aquifer. Geophysical and flowmeter surveys in a borehole 33P028 constructed in mid-November 2009 delineate several water-bearing zones bounded by less-permeable zones throughout the Floridan aquifer system. The Upper Floridan aquifer occurs at depths between 440 and 705 feet (ft) and is composed of two water-bearing zones - the 520 - to $650-\mathrm{ft}$ upper zone contributes 96 percent of the flow in the Upper Floridan aquifer; the 650 - to 705 -ft lower zone contributes the remaining 4 percent. The Lower Floridan confining unit extends from the base of the Upper Floridan to about $912 \mathrm{ft}$ and consists of three zones; the middle zone from 793 to $822 \mathrm{ft}$ depth is much more permeable than the top and bottom zones. Drill cores from the Lower Floridan confining unit at depths from 703 to $855 \mathrm{ft}$ indicate vertical hydraulic conductivities ranging from 0.26 to 0.79 feet per day $(\mathrm{ft} / \mathrm{d})$ and porosities ranging from 0.25 to 0.40 . The Lower Floridan aquifer extends from the base of the Lower Floridan confining unit to at least $1,300 \mathrm{ft}$ below land surface and contains three permeable zones-912-947 ft, 1,090-1,139 ft, and 1,211-1,250 ftinterlayered with three less-permeable zones.

Horizontal hydraulic conductivity estimates of the Lower Floridan confining unit were obtained from slug tests at four packer-isolated intervals in borehole 33P028-726.5-733.5 ft, $766.5-773.5 \mathrm{ft}, 816.5-823.5 \mathrm{ft}$, and $876.5-883.5 \mathrm{ft}$. Hydraulic conductivity in three of the four packer-isolated intervals was estimated by using a method for constant decay response back to static conditions. The isolated interval from $766.5-773.5 \mathrm{ft}$ depth had a slightly underdamped response (oscillation), and hydraulic conductivity was estimated using a method for oscillating responses. Horizontal hydraulic conductivity for each of the four intervals, with increasing depth, was 20, 70, 20, and $2 \mathrm{ft} / \mathrm{d}$, respectively.

Aquifer tests were conducted to estimate the transmissivity of the Upper and Lower Floridan aquifers and to determine the effects of pumping one aquifer on water levels in the other. For each test, drawdown was monitored in the pumping well and in two observation wells. Drawdown for the three monitored wells was estimated by using a procedure to filter water-level data for effects of barometric pressure, earth tide, and long-term trends.

A 24-hour aquifer test in which Upper Floridan aquifer well 33P029 was pumped at an average rate of 387 gallons per minute $(\mathrm{gal} / \mathrm{min})$ resulted in a total drawdown of $4.1 \mathrm{ft}$ in the pumped well and $0.2 \mathrm{ft}$ in Lower Floridan well 33P028. Analysis of drawdown data from the pumped well using a straight-line analytical method indicated the transmissivity, rounded to one significant figure, was $100,000 \mathrm{ft}^{2} / \mathrm{d}$.

A 72-hour aquifer test in which Lower Floridan aquifer well 33P028 was pumped at an average rate of $740 \mathrm{gal} / \mathrm{min}$ resulted in a maximum drawdown of $38.8 \mathrm{ft}$ in the pumped well and of 0.3 and $0.4 \mathrm{ft}$ in Upper Floridan aquifer observation well 33P025 (more than a mile from the pumped well) and well 33P029, respectively.

Drawdown data from the 72-hour test were used as a basis to estimate transmissivity of the Upper and Lower Floridan aquifers using the numerical model MODFLOW-96 with the calibration tool MODOPTIM. The aquifer system was simulated with a two-dimensional, axisymmetric, radial, transient groundwater-flow model that incorporated pumped well 33P028 and observation wells 33P029 and 33P025 and extended 200,000 ft from the pumped well and to a depth of 1,400 ft. Five hydrogeologic units are represented in the model - the surficial aquifer, Upper Floridan confining unit, Upper Floridan aquifer, Lower Floridan confining unit, and Lower Floridan aquifer. MODOPTIM was used to estimate horizontal hydraulic conductivity in the Upper Floridan aquifer, Lower Floridan confining unit, and Lower Floridan aquifer, and to estimate a single value for the composite specific storage of all five hydrogeologic units represented in the model. Transmissivity of the Lower Floridan aquifer was estimated to be about 7,000 $\mathrm{ft}^{2} / \mathrm{d}$. Transmissivity of the Upper Floridan aquifer was estimated to be $90,000 \mathrm{ft}^{2} / \mathrm{d}$, slightly less than the transmissivity that was determined by using drawdown data from a 24-hour aquifer test at well 33P029.

Parameter estimation and model simulation, in addition to collected data, indicate that the Lower Floridan confining unit at the study site has hydraulic properties similar to those of the Lower Floridan aquifer. The MODOPTIM estimated value of horizontal hydraulic conductivity of the Lower Floridan confining unit is essentially the same as that of the Lower Floridan aquifer. Further, model-parameter estimation results indicate a high measure of redundancy in the horizontal hydraulic conductivity of the Lower Floridan confining unit and the Lower Floridan aquifer. The high measure of redundancy for these two parameters indicates that MODOPTIM would provide a better estimate of the horizontal hydraulic conductivity for both the Lower Floridan confining unit and the Lower Floridan aquifer as a single hydrologic unit. The results of flowmeter surveys and slug tests support the hydrologic similarity between the two units at the study site. 


\section{References Cited}

Bouwer, H., and Rice, R.C., 1976, A slug test for determining hydraulic conductivity of unconfined aquifers with completely or partially penetrating wells: Water Resources Research, v. 12, no. 3, p. 423-428.

Clarke, J.S., Hacke, C.M., and Peck, M.F., 1990, Geology and ground-water resources of the coastal area of Georgia: U.S. Geological Survey and Georgia Department of Natural Resources, Bulletin 113, 106 p.

Clarke, J.S., and Krause, R.E., 2000, Design, revision, and application of ground-water flow models for simulation of selected water-management scenarios in the coastal area of Georgia and adjacent parts of South Carolina and Florida: U.S. Geological Survey Water-Resources Investigations Report 00-4084, 93 p.

Clarke, J.S., Leeth, D.C., Taylor-Harris, Da'Vette, Painter, J.A., and Labowski, J.L., 2004, Summary of hydraulic properties of the Floridan aquifer system in coastal Georgia and adjacent parts of South Carolina and Florida: U.S. Geological Survey Scientific Investigations Report 2004-5264, 52 p.

Cooper, H.H., and Jacob, C.E., 1946, A generalized graphical method for evaluating formation constants and summarizing well field history: American Geophysical Union Transactions, v. 27, p. 526-534.

Falls, W.F., Baum, J.S., Harrelson, L.G., Brown, L.H., and Jerden, J.L., Jr., 1997, Geology and hydrogeology of Cretaceous and Tertiary strata, and confinement in the vicinity of the U.S. Department of Energy Savannah River Site, South Carolina: U.S. Geological Survey WaterResources Investigations Report 97-4245, 125 p.

Georgia Environmental Protection Division, 2006, Coastal Georgia water \& wastewater permitting plan for managing salt water intrusion: Georgia Environmental Protection Division, 52 p., accessed December 1, 2010, at http://www1.gadnr.org/cws/Documents/saltwater management_plan_june2006.pdf.

Halford, K.J., 2006a, Documentation of a spreadsheet for timeseries analysis and drawdown estimation: U.S. Geological Survey Scientific Investigations Report 2006-5024, 38 p.

Halford, K.J., 2006b, MODOPTIM: A general optimization program for ground-water flow model calibration and groundwater management with MODFLOW: U.S. Geological Survey Scientific Investigations Report 2006-5009, 62 p.

Halford, J.H., and Kuniansky, E.L., 2002, Documentation of spreadsheets for the analysis of aquifer-test and slug-test data: U.S. Geological Survey Open-File Report 02-197, 51 p., accessed January 2010 at http://pubs.usgs.gov/ of/2002/ofr02197/.
Harbaugh, A.W., and McDonald, M.G., 1996, Progammer's documentation for MODFLOW-96, an update to the U.S. Geological Survey modular finite-difference groundwater flow model: U.S. Geological Survey Open-File Report 96-486, 220 p.

McDonald, M.G., and Harbaugh, A.W., 1988, A modular three-dimensional finite-difference ground-water flow model: U.S. Geological Survey Techniques of WaterResources Investigations, book 6, chap. A1, 576 p.

Miller, J.A., 1986, Hydrogeologic framework of the Floridan aquifer system in Florida and in parts of Georgia, Alabama, and South Carolina: U.S. Geological Survey Professional Paper 1403-B, Regional Aquifer System Analysis, 91 p., 33 pls.

Payne, D.F., Rumman, M.A., and Clarke, J.S., 2005, Simulation of ground-water flow in coastal Georgia and adjacent parts of South Carolina and Florida-Predevelopment, 1980, and 2000: U.S. Geological Survey, Scientific Investigations Report 2005-5089, 82 p.

Peck, M.F., Clarke, J.S., Ransom, Camille, III, and Richards, C.J., 1999, Potentiometric surface of the Upper Floridan aquifer in Georgia and adjacent parts of Alabama, Florida, and South Carolina, May 1998, and water-level trends in Georgia, 1990-98: U.S. Geological Survey, Hydrologic Atlas 22, map.

Randolph, R.B., Pernik, Maribeth, and Garza Reggina, 1991, Water-supply potential of Floridan aquifer system in the coastal area of Georgia - A digital model approach: Georgia Geologic Survey bulletin 116, 30 p.

Theis, C.V., 1935, The relation between the lowering of the piezometric surface and the rate and duration of discharge of a well using ground water storage: Transaction of American Geophysical Union, v. 16, p. 519-524.

van der Kamp, Garth, 1976, Determining aquifer transmissivity by means of well response tests - The underdamped case: Water Resources Research, v. 12, no. 1, p. 71-77.

Warren, M.A., 1944, Artesian water in southeastern Georgia: Georgia Geologic Survey Bulletin, No. 49, 140 p.

Weems, R.E., and Edwards, L.E., 2001, Geology of Oligocene, Miocene, and younger deposits in the coastal area of Georgia: Georgia Geologic survey bulletin 131, 124 p.

Williams, L.J., and Gill, H.E., 2010, Revised hydrogeologic framework of the Floridan aquifer system in the northern Coastal Plain of Georgia and adjacent parts of South Carolina: U.S. Geological Survey Scientific Investigations Report 2010-5158, 103 p. 
Manuscript approved for publication, January 5, 2011

Edited by Rebecca J. Deckard

Illustrations by Bonnie J. Turcott

Layout by Caryl J. Wipperfurth

For more information concerning the research in this report, contact USGS Georgia Water Science Center

3039 Amwiler Road

Atlanta, Georgia 30360

telephone: 770-903-9100

http://ga.water.usgs.gov 
步

है

웅

穴

꿍

읗 